\title{
Mamak (Ankara) Çalışan Petrol Sisteminin Jeokimyasal Kanıtı Olarak Olgun Hidrokarbonlarca Zengin Sular ve Bölgedeki Potansiyel Kapan Alanı
}

\author{
Adil ÖZDEMIR ${ }^{1 *}$ \\ ${ }^{1}$ Adil Özdemir Danışmanlık, Ankara, Türkiye \\ (Illk Geliş Tarihi 9 Temmuz 2019 ve Kabul Tarihi 21 Ekim 2019) \\ (DOI: $10.31590 /$ ejosat.589253)
}

\begin{abstract}
ATIF/REFERENCE: Özdemir, A. (2019). Mamak (Ankara) Çalışan Petrol Sisteminin Jeokimyasal Kanıtı Olarak Olgun Hidrokarbonlarca Zengin Sular ve Bölgedeki Potansiyel Kapan Alan1. Avrupa Bilim ve Teknoloji Dergisi, (17), 244-260.

$\ddot{O} \mathbf{z}$

$\mathrm{Bu}$ çalışma, Mamak (Ankara) bölgesinin jeokimyasal çalışmalar, tektonik ve jeofizik veriler ile petrol ve doğalgaz potansiyelinin değerlendirilmesi için yapılmıştır. Çalışma, üç aşamada yürütülmüştür. Birinci aşamada, literatürden çalışma alanının jeolojik özellikleri incelenmiştir. Böylece, jeokimyasal analizler ve jeofizik veri değerlendirmeleri için gerekli olan jeolojik veriler derlenmiştir. İkinci aşamada, çalışma alanının manyetik ve gravite haritaları hazırlanmıştır. Jeolojik ve jeofizik verilerin birlikte değerlendirilmesi sonucunda, çalışma alanında petrol kapanı olabilecek bir yapı belirlenmiştir. Üçüncü aşamada, belirlenen bu yapı üzerindeki ve çevresindeki çeşmelerinden (hayratlardan) alınan su numunelerinde Toplam Petrol Hidrokarbonları (TPH) analizleri yapılarak belirlenen yapının petrol ve doğalgaz potansiyeli değerlendirilmiştir. Yapılan analizler sonucunda, su numunelerin tamamında hidrokarbonlar tespit edilmiştir. Sularda tespit edilen hidrokarbonların kaynağının belirlenmesi için organik jeokimyasal yöntemler kullanılmıştır. Su numunelerinde belirlenen n-alkan hidrokarbonlar, olgun petrol hidrokarbonlarıdır. Bu olgun petrol hidrokarbonları, çalı̧̧ma alanında çalışan bir petrol sisteminin varlığı için kanıttır. Olgun petrol hidrokarbonları içeren suların varlı̆̆ı nedeniyle, gravite ve manyetik verilere göre çalışma alanında belirlenen maksimum $330 \mathrm{~m}$ derinliğindeki yapının bir petrol ve/veya doğalgaz rezervuarı olma potansiyeli oldukça yüksektir.
\end{abstract}

Anahtar Kelimeler: Karakaya karmaşı̆̆ı, Mamak, petrol ve doğalgaz arama, organik jeokimya, suda petrol analizi, hidrokarbonca zengin sular, hareketli hidrokarbonlar, yeraltısuyu kirliliği

\section{Mature Hydrocarbons-rich Waters as Geochemical Evidence of Working Petroleum System of Mamak (Ankara) and Potential Trap Area in the Region}

\begin{abstract}
This study is made to evaluate the oil and gas potential of the Mamak (Ankara) region with geochemical surveys, geophysical, and tectonic data. The study was conducted in three steps. In the first step, the geological characteristics of the study area from the literature were examined. Thus, the geological data to be required for geochemical analysis and geophysical data evaluations were compiled. In the second step, aeromagnetic and gravity maps of the study area were prepared. As a result of evaluating these data together, a structure that could be a petroleum trap was determined in the study area. In the third stage, total petroleum hydrocarbons (TPH) analyses in the samples taken from the water fountains on and around this determined structure were conducted and the oil and gas potential of the determined structure were evaluated. As a result of this analysis, it has been determined hydrocarbons in all water samples. To determine the source of hydrocarbons in the waters have used organic geochemical methods. The $\mathrm{n}$-alkane hydrocarbons in water samples are mature petroleum hydrocarbons. The mature hydrocarbons are evidence for a working petroleum system in the study area. Due to the presence of waters containing mature petroleum hydrocarbons, the structure in maximum $330 \mathrm{~m}$ depth determined in the study area according to gravity and magnetic data has very high potential to become an oil and/or gas reservoir.
\end{abstract}

Keywords: Karakaya complex, Mamak, oil and gas exploration, organic geochemistry, oil in water analysis, hydrocarbon-rich waters, mobile hydrocarbons, groundwater contamination

* Sorumlu Yazar: Adil Özdemir Danışmanlık, Ankara, Türkiye, ORCID: 0000-0002-3975-2846, adilozdemir2000@yahoo.com 


\section{Giriş}

Çalışma alanı olan Mamak (Ankara) bölgesinde (Şekil 1), geniş alanlar kaplayan Karakaya karmaşı̆̆ı üzerine çok sayıda genel jeoloji amaçlı araştırma yapılmıştır (Sayit, 2010; Okay ve Göncüoğlu, 2004; Bozkurt, 1990; Çelik, 1989; Koçyiğit, 1987). Bu çalışma ise, inceleme alanının ana birimi olan Karakaya karmaşığının petrol ve doğalgaz potansiyelinin değerlendirilmesini amaçlamaktadır. Çalışma alanında geniş yayılım sunan Karakaya karmaşığının bu çalışmada petrol ve doğalgaz potansiyelinin değerlendirilmesinin nedeni, Hasanoğlan (Ankara) bölgesinde yapılan öncel çalışmada (Özdemir, 2019a), Karakaya karmaşı̆̆ı birimleri ile ilişkili olan sulardan alınan örneklerde olgun ham petrol (petrojenik) hidrokarbonlarının belirlenmiş olmasıdır.

Çalışma alanı ve civarında üç ana jeolojik birim görülmektedir. Bunlar; yaşlıdan gence doğru Karakaya karmaşı̆̆ı, Ankara grubu, Anadolu karmaşığı ve örtü kayalarıdır (Şekil 1). Karakaya karmaşı̆̆ kuvvetli şekilde deforme, bazı kısımları metamorfizmaya uğramış Permiyen ve Triyas yaşlı birimlerden oluşur. Karakaya karmaşı̆̆ı, alt ve üst olmak üzere iki alt birime ayrılmıştır. Alt Karakaya karmaşı̆̆ sedimanter, volkanoklastik ve volkanik kayalardan meydana gelir. Üst Karakaya karmaşığı içinde, çok sayıda Karbonifer ve Permiyen yaşı kireçtaşı bloğu bulunmaktadır. Ankara grubu, Geç Jura-Erken Kretase yaşlı olup, birim arasındaki ilişki, tektoniktir. Yaşlı birimlerin tamamı, Geç Kretase-Kuvaterner yaşlı birimler tarafindan uyumsuz olarak örtülmektedir (Sayit, 2010; Bozkurt, 1990; Koçyiğit, 1987). Karakaya Karmaşı̆̆ı; bir rift veya Jura-öncesi Paleotetis okyanusunun kapanması ile oluşan dalma-batma yığışım prizması veya her iki ortamın kalıntılarını temsil eden birimlerden oluşmakta ve iki bölüme ayrılmaktadır (Şekil 1). Alt Karakaya karmaşı̆̆1, Paleozoyik sonu veya Triyas’ta metamorfizma geçirmiş mavişist ve yeşilşist fasiyesi (metapelitler; sleyt, fillit, şist; metasilttaşı, metakumtaşı, metakireçtaşı, metadolomit, mermer, metavolkanik, metatüfit, metabazalt, metagabro, metadiyabaz) kayaçları ile temsil edilmektedir. Üst Karakaya karmaşı̆̆ı, içerisinde çok sayıda Permokarbonifer yaşlı ortama yabancı kireçtaşı blokları içeren Permiyen ve Triyas yaşlı kuvvetlice deforme olmuş metakumtaşları, metapelitik kayaçlar (çamurtaşı, şeyl, sleyt, silttaşı), spilitik metabazalt/bazalt-aglomeraları ve metakireçtaşlarından oluşmaktadır (Tetiker ve diğ., 2015).

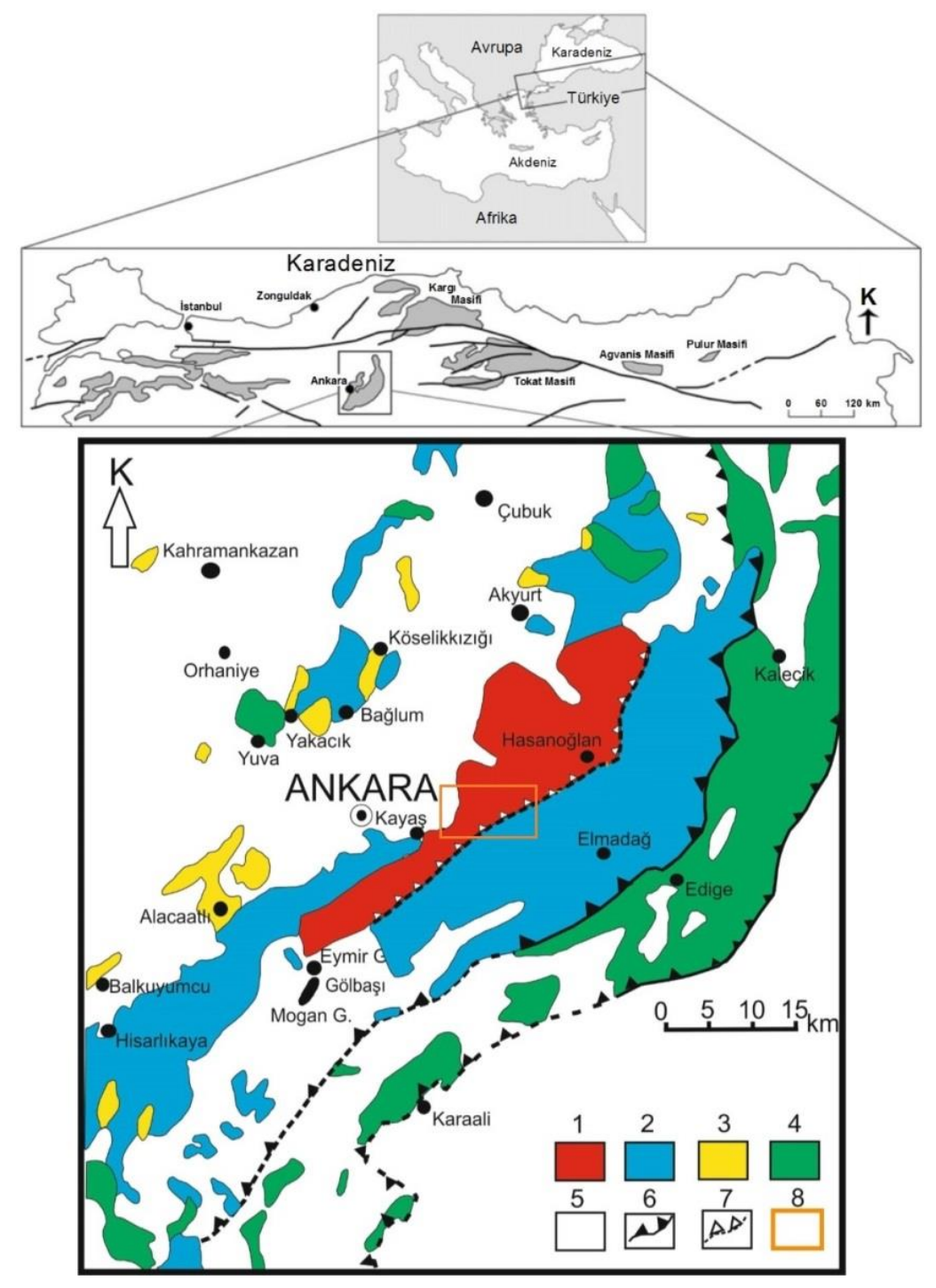

Şekil 1. Karakaya karmaşı̆̆ının Türkiye kuzeyindeki dağılımı (üst haritadaki gri renkli alanlar) ve Ankara'nın basitleştirilmiş jeoloji haritası. 1. Üst Karakaya napı, 2. Alt Karakaya napı, 3. Ankara grubu, 4. Anadolu napı, 5. Örtü kayaları, 6. Bindirme fayl, 7. Ters fay, 8. Çalışma alanı (Sayit, 2010; Bozkurt, 1990; Koçyiğit, 1987 'den düzenlenmiştir). 
Liu ve diğ. (2018), Kuzeybatı Guizhou (Çin) Triyas akiferlerinin yeraltısuyu numunelerinde yaptıkları gaz kromatografisi analizlerinde, ham petrol kökenli n-alkan hidrokarbonları tespit etmişlerdir. Hidrokarbon miktarı $>0.05 \mathrm{mg} / \mathrm{lt}$ olan yeraltısularını, hidrokarbonca zengin yeraltısuyu olarak tanımlamışlardır (Çin standartlarına göre ikinci derecede içmesuyu kaynağı). Çalışma alanında 5 yıl süreyle yapılan yeraltısuyu gözlemlerinde, yeraltısularındaki petrol hidrokarbonu miktarının daima $>0.05 \mathrm{mg} / \mathrm{lt}$ olduğu bildirilmiştir. Düşük düzeydeki antropojenik kirlenmenin, bölgedeki hidrokarbonca zengin yeraltısularını üretemeyeceği belirlenmiştir. Bölgedeki kayaçların hidrokarbon potansiyelinin ve sığ yeraltısularındaki hidrokarbonların kaynağının belirlenmesi ve karşılaştırılması için organik jeokimyasal ve biomarker karakteristikleri kullanılmışır. Bölgedeki kayaçlarda yapılan organik jeokimyasal değerlendirmelerde, kayaçların yüksek hidrokarbon potansiyeline sahip olduğu belirlenmiştir. Yeraltısularında tespit edilen hidrokarbonların, orijinal hidrokarbonlar olduğu belirlenmiştir. Ayrıca, bölgedeki kayaç ve derin yeraltısularından alınan numunelerin organik jeokimyasal ve biomarker karakteristiklerinin birbiri ile uyumlu olduğu görülmüştür (Şekil 2). Sığ akiferlerdeki hidrokarbon miktarının, su-kayaç-hidrokarbon etkileşimi ile arttı̆̆ı belirlenmiştir. Sı̆̆ yeraltısularından daha ziyade, derin yeraltısularında bölgedeki kayaçlardakine benzer dağılım gösteren doymuş karbonlar bulunduğu tespit edilmiştir. Bu sonuçlara göre, sı ğ ve derin yeraltısularındaki yüksek miktardaki orijinal hidrokarbonların kaynağının, bölgedeki yüksek hidrokarbon potansiyelli kayaçlardan hidrokarbon salınımı olduğu belirtilmiştir.

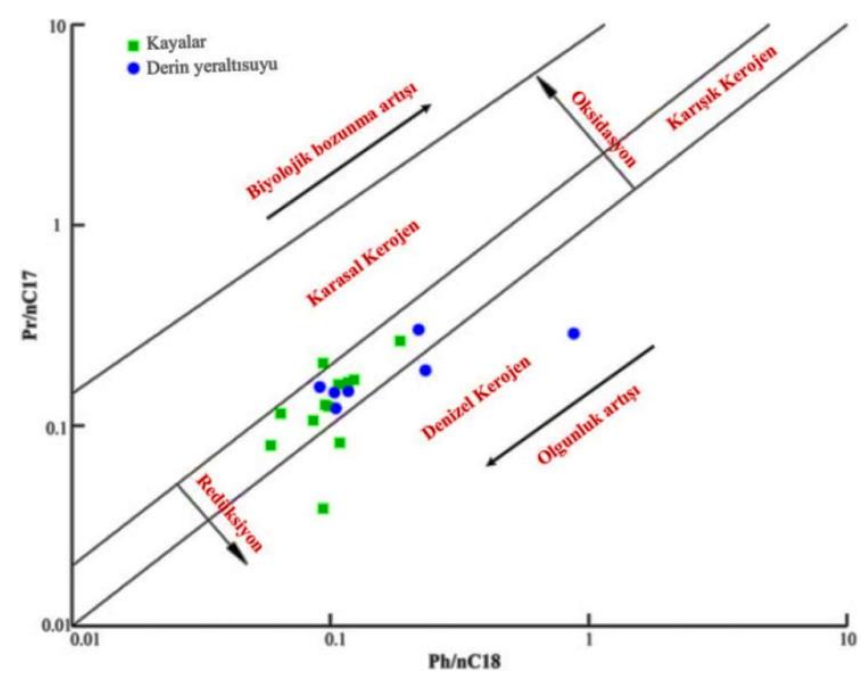

Şekil 2. Ayn bölgeden alınan kaynak kaya ve derin yeraltısuyu numunelerinin Pr/n-C17-Ph/n-C18 diyagramı (Liu ve diğ., 2018)

Özdemir (2018) çalışmasında, Suda Petrol (TPH) analizinin petrol ve doğalgaz aramada kullanılabilirliğinin incelenmesi amaçlanmıştır. Bu amaçla, Yüksekova (Hakkari), Ulukışla (Niğde) ve Hasanoğlan (Ankara) bölgeleri yeraltısularında yapılan TPH analizlerine ait sonuçlar, aynı bölgedeki klasik petrol jeokimyası analiz sonuçları ile karşılaştırılmıştır. Her üç bölgede yapılan hidrojeokimyasal analiz ve değerlendirme sonuçları ile su numunelerinin alındığı bölgedeki kaynak kaya ve gaz örneklerinde yapılan organik jeokimyasal analiz sonuçları ve değerlendirmeleri birbiri ile uyumlu çıkmıştır (Li ve diğ., 2018 çalışmasında olduğu gibi). İncelenen su numunelerinin tamamının TPH değerlerinin yeraltısuları için önerilen sınır değerden oldukça yüksek olduğu görülmüştür. Ayrıca, her üç bölge sularında da ham petrol kaynaklı n-alkan hidrokarbonlar tespit edilmiştir. TPH değerinin, kaynak kaya tarafindan türetilmiş ve rezervuar kayaya gönderilmiş olgun hidrokarbonları temsil ettiği ve TPH $>0.5 \mathrm{mg} / \mathrm{lt}$ değerine sahip ve olgun hidrokarbon içeren yeraltısularının, bulunduğu bölgedeki petrol ve doğalgaz yatakları ile ilişkili sular olduğu belirtilmiştir. Çalışmada, rezervuar hedefli suda TPH analizlerinin petrol aramacılığında pratik ve etkili bir jeokimyasal yöntem olarak kullanılabileceği ve bu yöntemle petrol ve doğalgaz yatakları bulunduran havzaların belirlenebileceği sonucuna ulaşıldığı bildirilmiştir. Diğer jeolojik ve jeofizik yöntemler ile birlikte kullanılması durumunda da, hidrokarbon arama riskini en aza indirmek ve ticari üretim yapılabilir yeni petrol ve doğalgaz yataklarının keşfedilebilmesi için pratik ve etkili bir araç olarak kullanılabileceği ve arama risk ve maliyetlerinin büyük ölçüde azaltılabileceğinin düşünüldüğü bildirilmiştir. Çalışmada, bir petrol ve/veya doğalgaz rezervuarı etrafında olgun hidrokarbonlarca zengin bir su havzasının bulunduğu belirtilmiştir (Şekil 3). Dolayısıyla, çalışma alanında bir petrol ve/veya doğalgaz rezervuarının var olması durumunda, çalışma alanındaki yeraltısularının hidrokarbonca zengin olması gereklidir.

Özdemir (2019a) çalışmasında, Hasanoğlan (Ankara) soğuksu çeşmelerinden (hayratlardan) topladığı numunelerde yaptığı TPH analizlerinde, ham petrol kökenli (petrojenik) n-alkan hidrokarbonları tespit etmiş̧ir. Çalışmada, su numunelerindeki hidrokarbonların kökeni, olgunluk durumları, çökelme ortamları vb. organik jeokimyasal açıdan yorumlanmıştır. Olgun petrol hidrokarbonlarca zengin suların üretim yapılabilir bir petrol sisteminin kanıtı olduğu belirtilmiştir. Olgun petrol hidrokarbonlarınca zengin su kaynaklarının varlığı nedeniyle, Hasanoğlan bölgesinin yüksek petrol ve doğalgaz potansiyeline sahip olduğu bildirilmiştir.

Özdemir (2019b) çalışmasında, Büyük Menderes grabeninin (Batı Anadolu) batı kısmında, Aydın ili sınırları dahilinde elektrik üretimi amaçlı olarak kullanılan, yüksek sıcaklıklı $\left(>150{ }^{\circ} \mathrm{C}\right)$ buhar baskın akışkan içeren ve derinlikleri 1500 - $2500 \mathrm{~m}$ olan jeotermal kuyulardan topladığı su numunelerinde yaptığı TPH analizlerinde, ham petrol kökenli (petrojenik) n-alkan hidrokarbonları tespit etmiş̧ir. Çalışmada, sıcaksu numunelerindeki hidrokarbonların kökeni, olgunluk durumları, çökelme ortamları vb. gibi özellikleri organik jeokimyasal açıdan yorumlanmıştır. Olgun petrol hidrokarbonlarca zengin suların üretim yapılabilir bir petrol sisteminin kanıtı olduğu belirtilmiş̧tir. Olgun petrol hidrokarbonlarınca zengin su kaynaklarının varlı̆̆ nedeniyle, çalışma alanında belirlenmiş olan yapıların (kapanların) yüksek petrol ve doğalgaz potansiyeline sahip olduğu bildirilmiştir. 


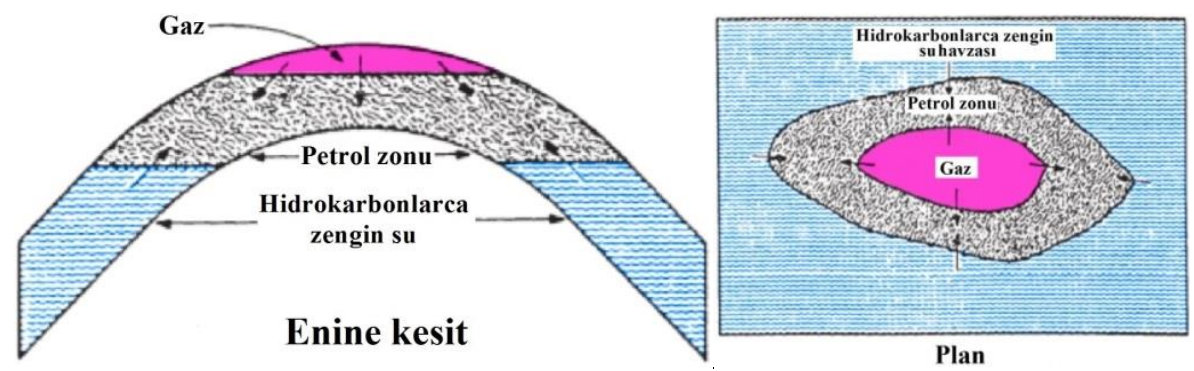

Şekil 3. Birincil yöntemlerle üretim yapılan antiklinal bir petrol rezervuarının bileşenleri (Özdemir, 2018'den).

Çalışma, üç aşamada yürütülmüştür. Birinci aşamada, literatürden çalışma alanının jeolojik özellikleri incelenmiştir. Böylece, jeokimyasal analizler ve jeofizik değerlendirmeler için gerekli olan jeolojik veriler derlenmiştir. İkinci aşamada, çalışma alanının manyetik ve gravite haritaları hazırlanmıştır. Jeolojik ve jeofizik verilerin birlikte değerlendirilmesi sonucunda, çalışma alanında petrol kapanı olabilecek bir yapı belirlenmiştir. Üçüncü aşamada, belirlenen bu yapı üzerindeki ve çevresindeki çeşmelerinden (hayratlardan) alınan su numunelerinde Toplam Petrol Hidrokarbonları (TPH) analizleri yapılarak belirlenen yapının petrol ve doğalgaz potansiyeli değerlendirilmiştir. Yapılan analizler sonucunda, su numunelerin tamamında olgun petrol hidrokarbonları tespit edilmiştir. Tespit edilen olgun hidrokarbonlar, çalışma alanında çalışan bir petrol sisteminin varlığı için kanıttır.

\section{Materyal ve Yöntem}

Çalışma alanındaki yeraltısularının hidrokarbon içeriklerini belirlemek amacıyla, bölgedeki çeşmelerinden (hayratlardan) 1 litre ölçekli plastik kaplarla klasik hidrojeokimyasal örnek alım yöntemi ile 5 adet su numunesi alınmıştır (Şekil 4 ve 5). Alınan su numunelerinde, organik jeokimyasal değerlendirmelere veri oluşturmak amaciyla Türkiye Petrolleri (TPAO) Ar-Ge Merkezinde Agilent 7890A gaz kromotografi cihazı ile TPH (Toplam Petrol Hidrokarbonları) analizleri yapılmıştır. Bu analizler ile su numunelerinin TPH konsantrasyonları (mg/lt cinsinden) belirlenmiş ve jeokimyasal değerlendirmelerde bu konsantrasyonlar kullanılmıştır.

Toplam Petrol Hidrokarbonları (TPH)'nin saptanması, yeraltısularının hidrokarbon kirliliği hakkında bilgi vermektedir. TPH analizi, C10 - C40 karbon aralığında kalan alan yardımıyla TPH değerinin (hidrokarbon miktarının) hesaplanmasıdır. Bu karbon yelpazesi, düşük kaynama noktasına sahip uçucu hidrokarbon bileşiklerinden, yüksek kaynama noktası aralığında bulunan uçucu olmayan bileşiklere kadar uzanmaktadır (Sakroon, 2008). Sudaki TPH konsantrasyonlarını belirlemek için gaz kromatografisi (GC) analizleri yapılmaktadır. Suda TPH tayininde (Suda Petrol), TS EN ISO 9377-2, 2000 sayılı Hidrokarbonların Tayini - Bölüm 2: Çözücü Ekstraksiyonu ve Gaz Kromatografi Yöntemi standart testi kullanılmaktadır (Diğer yöntemler, EPA Metot 1664 ve ASTM D7678-11). Bu analiz yönteminde yerüstü, yeraltı ve dağıtım sularından alınan örneklerdeki hidrokarbonlar ayrılmakta ve su numunesindeki toplam petrol hidrokarbonlarının miktarı tayin edilmektedir.

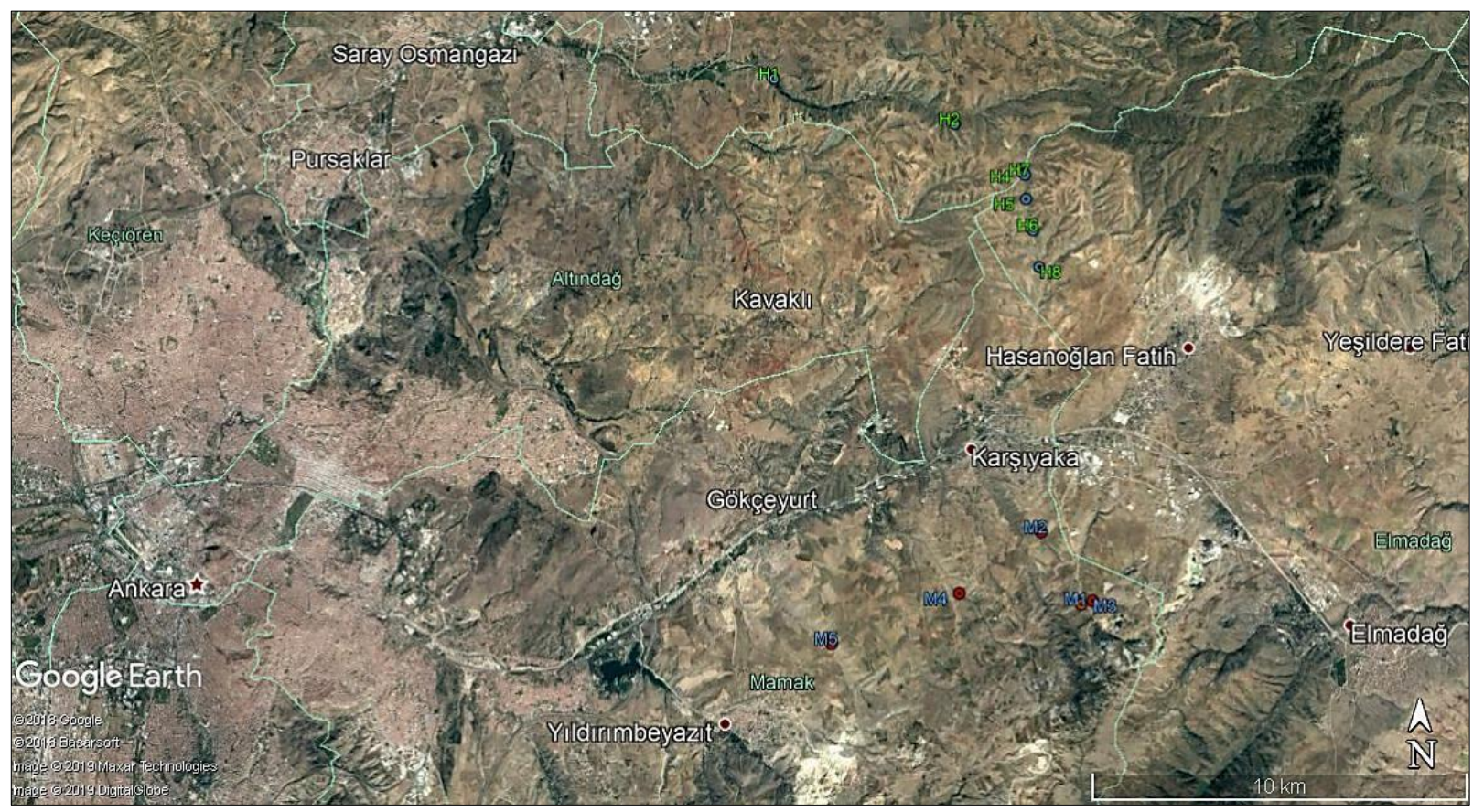

Şekil 4. Numune alınan su kaynaklarının yerbulduru haritası (M: Bu çalışmanın Mamak su numuneleri, H: Özdemir (2019a) çalışmasındaki Hasanoğlan su numuneleri) 


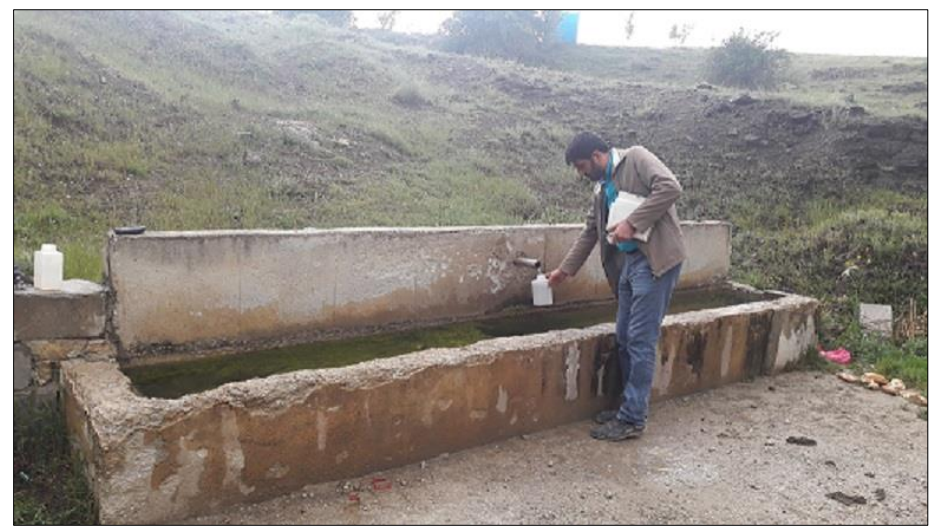

Şekil 5. Çalışma alanındaki su kaynaklarından 1 litre ölçekli plastik kaplarla su numunesi alınması

\section{Bulgular ve Tartışma}

Çalışma alanından alınan su numuneleri üzerinde yapılan TPH analiz sonuçları esas alınarak; sulardaki hidrokarbonların miktarı, bozunma durumu ve kaynağı, olgunluğu ve çökelme ortamının redoks koşulları jeokimyasal açıdan incelenmiştir. Ayrıca, inceleme alanı için hazırlanan havadan manyetik ve gravite haritaları jeolojik ve tektonik açıdan yorumlanmış ve hidrokarbonların kavramsal oluşum, göç ve birikme modelinin kurgulanması amaçlanmıştır.

\subsection{Sulardaki Hidrokarbonların Miktarı ve Kaynağı}

Yeraltısuyu, petrol ve doğalgaz rezervuarı oluşumu için belirleyici faktördür. Diyajenetik ortam, hidrokarbonların göçünü ve ayrışmasını kontrol eder (Liu ve diğ., 2018; Li ve diğ., 2014; Feng ve Han, 2002). Su-kayaç-hidrokarbon etkileşimi, petrol ve doğalgaz rezervuarının mekânsal evrimi için anahtar faktördür ve tüm diyajenetik süreçte işlev görür (Liu ve diğ., 2018; Cai ve diğ., 1997). Bu etkileşim; minerallerin tümü, organik madde ve formasyon suyu içeren, hem tepkiyen hem de ürün oluşum süreçlerinin bir arada bulunduğu karmaşık bir fizikokimyasal işlemdir. Bu işlemde, özel sıcaklık ve basınç koşullarında ayrışma ve çökelme arasında dinamik bir dengeye ulaşılmaktadır. Su-kayaç-hidrokarbon etkileşimi için en belirgin manifesto, yeraltısuları ve formasyonlardaki fizikokimyasal özellik değişimidir. Bu etkileşim, yeraltısularında hidrokarbonlarca zenginleşmeye sebep olur (Liu ve diğ., 2018). Liu ve diğ. (2018), hidrokarbon içeriği $0.05 \mathrm{mg} / \mathrm{lt}$ 'yi aşan yeraltısuyunu orijinal hidrokarbonca zengin yeraltısuyu olarak tanımlamıştır. Mamak (Ankara) bölgesinden alınan su numunelerinde yapılan TPH analizlerinde, su numunelerin tamamında n-alkan hidrokarbonlar tespit edilmiștir (Tablo 1). İnceleme alanındaki su numunelerinin TPH değerlerinin, Liu ve di ̌̆ (2018) tarafindan önerilen (hidrokarbon içeriği $<0.05 \mathrm{mg} / \mathrm{lt}$ ) ve Özdemir (2018) tarafindan önerilen (TPH $<0.5 \mathrm{mg} / \mathrm{lt}$ ) yeraltısularında bulunması gereken hidrokarbon sınır değerlerinden oldukça yüksek olduğu görülmektedir (Tablo 1). Dolayısıyla, su-kayaç-hidrokarbon etkileşimi, inceleme alanındaki sularda hidrokarbon zenginleşmesine sebep olmuştur.

Tablo 1. Su örneklerinin TPH analiz sonuçları ve hesaplanan jeokimyasal parametreler

\begin{tabular}{|c|c|c|c|c|c|c|c|c|}
\hline \multirow{2}{*}{$\begin{array}{c}\text { Numune } \\
\text { No }\end{array}$} & \multicolumn{2}{|c|}{ Koordinatlar } & $\begin{array}{c}\text { TPH } \\
\text { (mg/lt) }\end{array}$ & CPI & NAR & Pr/Ph & Pr/n-C17 & Ph/n-C18 \\
\cline { 2 - 8 } & $\mathrm{X}$ & $\mathrm{Y}$ & & & & & & \\
\hline M1 & 4419750 & 512105 & 7.51 & 1.12 & 0.03 & 0.57 & 0.25 & 0.58 \\
\hline M2 & 4421691 & 511081 & 8.47 & 1.78 & 0.17 & 0.54 & 0.60 & 0.71 \\
\hline M3 & 4419843 & 512413 & 12.80 & 1.28 & 0.13 & 0.41 & 0.36 & 0.40 \\
\hline M4 & 4420054 & 508805 & 13.71 & 1.09 & 0.28 & 0.54 & 0.57 & 0.38 \\
\hline M5 & 4418725 & 505317 & 9.20 & 0.97 & 0.02 & 0.82 & 0.51 & 0.09 \\
\hline
\end{tabular}

Gaz kromatogramlarından elde edilen jeokimyasal parametrelerin değerlendirildiği grafiğe bakıldığında (Şekil 6), Hasanoğlan su numunelerindeki hidrokarbonların bir kısmının normal petrol sınıfına girdiği, Hasanoğlan su numunelerinin bir kısmı ve Mamak su numunelerinin tamamının normal petrollerin biyodegragasyona uğraması sonucunda kalıntı ürününe dönüşme eğiliminde olduğu görülmektedir. Kaynak, olgunlaşma, göç ve biyolojik bozunma, hidrokarbonların bileşimindeki farklılıklardan sorumlu ana faktörlerdir. $\mathrm{Ph} / \mathrm{n}-\mathrm{C} 18$ değeri $<1$ ise, biyolojik olarak bozunmamış hidrokarbonları göstermektedir (Hunt, 1995). Su numunelerinin tümünün $\mathrm{Ph} / \mathrm{n}$-C18 değeri, < 1'dir (Tablo 1). Bu değerlere göre, su numunelerindeki hidrokarbonlar biyolojik olarak bozunmamıştır.

Hidrokarbon bileşiklerinin genel dağılımlarını görmek, organik madde tipi, olgunlaşma ve çökelme ortamları hakkında bilgi sağlamak amacıyla gaz kromatografi analiz sonuçları kullanılarak Pristan ( $\mathrm{Pr}$ ) / Fitan (Ph) oranı, izoprenoid/n-alkan oranı ve Karbon Tercih İndeksi (CPI) hesaplanarak yorumlamaya gidilmektedir. Bu çalışmada, n-alkan dağılımlarından yararlanılarak su numuneleri Pr/Ph oranı (Didyk ve diğ., 1978; Tissot ve Welte, 1984; Banga ve diğ., 2011), CPI indeksi (Bray ve Evans, 1961;1965), Pr/Ph - CPI (Hakimi ve diğ., 2017; Onojake ve diğ., 2013), Pr/nC17 - Ph/nC18 (Peters ve diğ., 1999; Sar1 ve diğ., 2003; Mathur ve diğ., 1988) ve $\mathrm{Pr}+\mathrm{Ph} / \mathrm{nC} 17+\mathrm{nC} 18$ (Frimmel ve diğ., 2004) diyagramlarında jeokimyasal açıdan yorumlanmıştır. 


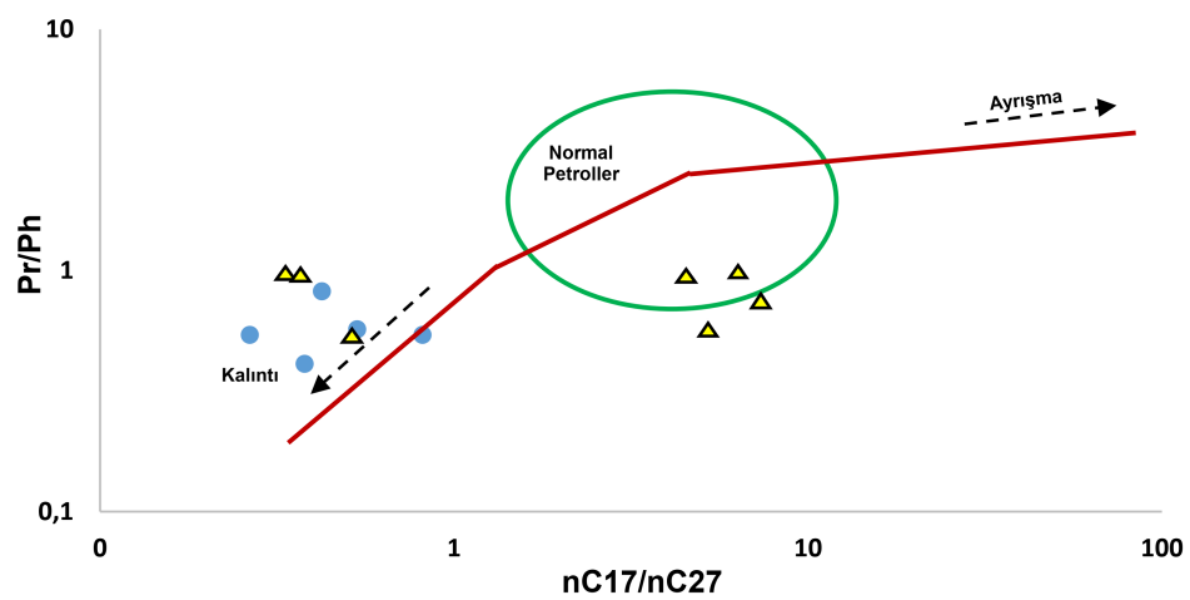

Şekil 6. Pr/Ph - nC17/nC27 grafiği (Çorbacıoğlu ve diğ., 2018). Mavi renkli daireler: Mamak (Ankara) su numuneleri, sarı renkli üçgenler: Hasanoğlan (Ankara) su numuneleri (Şekil 2; Özdemir, 2019a)

CPI, n-alkan kaynağının bir göstergesidir. Tek ve çift karbon numaralı n-alkan miktarları arasındaki bir oran olan CPI, gaz kromatogramlarındaki piklerin yükseklikleri veya alanları ölçülerek belirlenmektedir ( $\mathrm{Bu}$ çalışmada, pik alanları kullanılmıştır). Bu kromatogramlarda hâkim pikler, n-alkanlardır. CPI indeksinin hesaplanmasında, farklı araştırmacılar farklı formüller önermişlerdir. $\mathrm{Bu}$ indeks, karbon dizisinin herhangi bir aralığına uygulanabilmektedir. $\mathrm{CPI}$ indeksinin hesaplanması: $\mathrm{CPI}=1 / 2 \mathrm{x} \mathrm{CPI}=\left[\left(\mathrm{C}_{17}+\mathrm{C}_{19}+\right.\right.$ $\left.\left.\mathrm{C}_{21}+\mathrm{C}_{23}\right) /\left(\mathrm{C}_{16}+\mathrm{C}_{18}+\mathrm{C}_{20}+\mathrm{C}_{22}\right)\right]+\left[\left(\mathrm{C}_{17}+\mathrm{C}_{19}+\mathrm{C}_{21}+\mathrm{C}_{23}\right) /\left(\mathrm{C}_{18}+\mathrm{C}_{20}+\mathrm{C}_{22}+\mathrm{C}_{24}\right)\right] / 2$ (Bray ve Evans, 1961; 1965).

$\mathrm{CPI}$, tek ve çift numaralı n-alkanların birbirlerine göre bolluğu, organik madde tipi, çökelme ortamı ve isısal olgunluğu yorumlamada kullanılmaktadır. CPI değerinin belirgin bir şekilde 1'den büyük (tek n-alkan tercihli) veya 1'den küçük (çift n-alkan tercihli) olması 1sısal ortamlarla ilişkili petrol ve bitümlerde gözlenmektedir (Tissot ve Welte, 1984; Peters ve Moldowan, 1993). Yüksek CPI değeri, yüksek karasal bitkilerden türemiş, olgunlaşmamış veya olgunluğu düşük organik maddeyi yansıtmaktadır (Tran ve Philippe, 1993). CPI değerlerine göre (Tablo 1), incelenen su numunelerindeki n-alkanların kaynağı petrojenik hidrokarbonlar ve organik maddece zengin yaşlı sedimanlardır (Tablo 2)

Tablo 2. CPI dĕgerine göre sudaki n-alkanların kaynă̆ı (Özdemir, 2018)

\begin{tabular}{|c|c|}
\hline CPI & Kaynak \\
\hline$>2.3$ & $\begin{array}{c}\text { Güncel karasal sedimanlar } \\
\text { (biyojenik hidrokarbonlar) }\end{array}$ \\
\hline $1.2-2.3$ & $\begin{array}{c}\text { Organik maddece zengin yaşlı sedimanlar } \\
\text { (denizel şeyller, karbonatlar vb.) }\end{array}$ \\
\hline$\leq 1.2$ & $\begin{array}{c}\text { Petrojenik hidrokarbonlar } \\
(<1 \text { değerler bozunmuş petroller) }\end{array}$ \\
\hline
\end{tabular}

Petrojenik kaynaklar terimi; ham petrol ve kömür vb. gibi yanmamış fosil kaynakları tanımlamaktadır. Bu kaynaklar, milyonlarca yıl önce ve orta sıcaklıklarda $\left(100-300{ }^{\circ} \mathrm{C}\right.$ arasında) çok yavaş bir şekilde oluşmuştur (Beyer ve diğ., 2010). Ortamdaki hidrokarbonların kaynağını (doğal veya petrol n-alkan) değerlendirmek için NAR (Doğal N-alkan Oranı) olarak tanımlanan bir parametre önerilmiştir (Mille ve diğ., 2007). Bu oran, petrol hidrokarbonları ve ham petroller için sıfır veya sıfıra çok yakındır. Diğer kaynaklar için ise, daha yüksek olarak belirtilmiştir. NAR parametresine göre (Tablo 1), incelenen su numunelerindeki n-alkanların tamamı, doğal petrol (petrojenik) hidrokarbonlarıdır. NAR parametresi aşağıdaki formülle hesaplanmaktadır.

$\mathrm{NAR}=\frac{\left[\sum n \text {-alk }\left(\mathrm{C}_{19-32}\right)-2 \sum \text { çift } n \text {-alk }\left(\mathrm{C}_{20-32}\right)\right]}{\sum n \text {-alk }\left(\mathrm{C}_{19-32}\right)}$

\subsection{Sulardaki Hidrokarbonların Olgunluğu ve Çökelme Ortamının Redoks Koşulları}

Olgun hidrokarbonların CPI değeri, 1'dir veya 1'e çok yakındır (Waples, 1985). Çok tuzlu karbonat veya evaporitik ortamlarla ilişkili petrol ve bitümlerin CPI değerleri, 1'den küçüktür (Tissot ve Welte, 1984; Peters ve Moldowan, 1993). Onojake ve diğg. (2013) çalışmalarında, CPI değerlerini esas alarak hidrokarbonları olgunluklarına göre sınıflandırmışlardır (Tablo 3). Bu sınıflamaya göre, incelenen su numunelerindeki (Tablo 2) hidrokarbonların tamamına yakını olgundur.

Tablo 3. CPI değerine göre hidrokarbonların olgunluk derecesi (Onojake ve diğ., 2013'den düzenlenmiştir) (bkz. Şekil 7)

\begin{tabular}{|c|c|}
\hline CPI & Olgunluk \\
\hline $1-1.4$ & Olgun (okside-redükte) \\
\hline $0.8-1$ & Olgun \\
\hline$<0.8$ & Olgunlaşmamış \\
\hline
\end{tabular}


İzoprenoid/n-alkan oranlarında, gaz kromatogramlarındaki izoprenoidlere en yakın n-alkanlar kullanılmaktadır. $\mathrm{Pr} / \mathrm{Ph}$ oranı, iyi bir korelasyon parametresidir. Pristan $(\mathrm{Pr})$ ve fitan $(\mathrm{Ph})$, özellikle fototropik organizmalardaki klorofilin yan zinciri olan fitilden türemektedir. Anoksik koşullar altında fitil yan zinciri koparak fitolü ve fitolde indirgenerek fitanı oluştururken, oksik koşullar altında ise fitol pristana indirgenmektedir (Peters ve Moldowan, 1993). Dolayısıyla, $\mathrm{Pr} / \mathrm{Ph}$ oranı çökelme ortamının redoks potansiyelini yansıtmaktadır. $\mathrm{Pr} / \mathrm{Ph}<1$ ise anoksik, $\mathrm{Pr} / \mathrm{Ph}>1$ ise oksik çökelme ortamı işaret etmektedir (Didyk ve diğ.. 1978). İncelenen su numunelerinin tamamı, anoksik ortamda $(\mathrm{Pr} / \mathrm{Ph}<1)$ çökelmiş sedimanlardan türemiş hidrokarbonları içermektedir $(\mathrm{Tablo} 2) . \mathrm{Pr} / \mathrm{Ph}$ oranı, ayrıca paleoortam ve olgunluk hakkında da bilgi sağlamaktadır (Volkman ve Maxwell, 1986). Pr/Ph-CPI diyagramında, incelenen su numunelerindeki hidrokarbonların fazla redükte alanda yer aldığı ve benzer olgunluk seviyelerinde olduğu görülmektedir (Şekil 7).

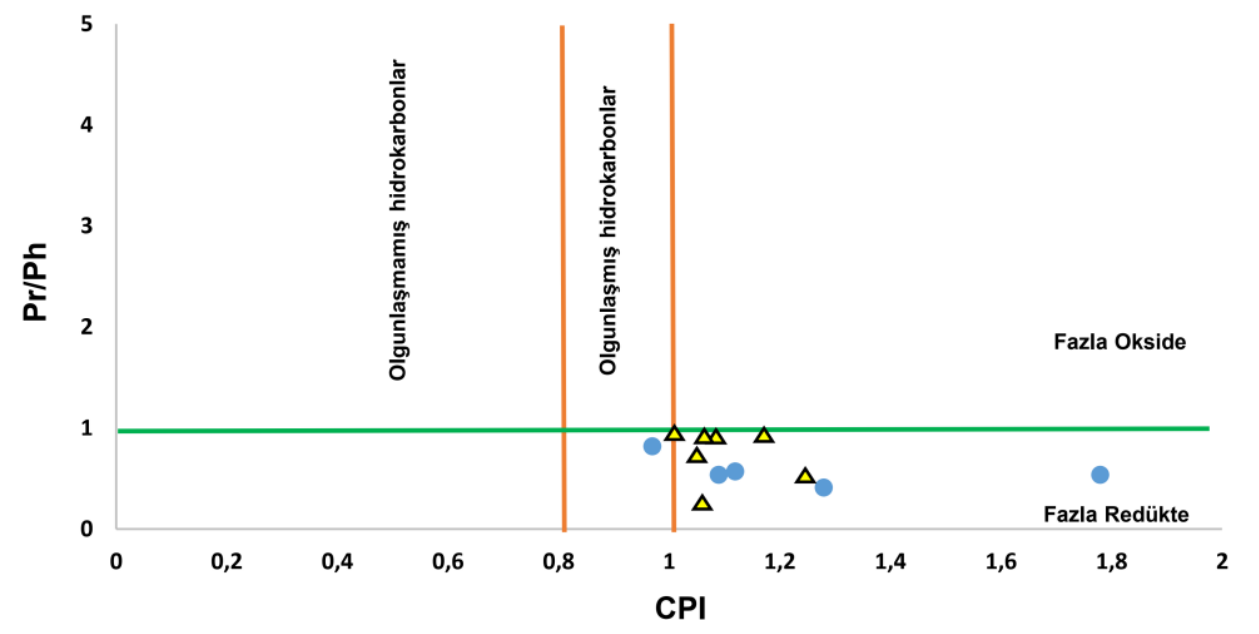

Şekil 7. Pr/Ph - CPI diyagramı (Onojake ve diğ., 2013). Mavi renkli daireler: Mamak (Ankara) numuneleri, sarı renkli üçgenler: Hasanoğlan (Ankara) numuneleri (bkz. Şekil 2; Özdemir, 2019a)

$\mathrm{Pr} / \mathrm{n}-\mathrm{C} 17$ ve $\mathrm{Ph} / \mathrm{n}-\mathrm{C} 18$ oranları, hidrokarbon korelasyon çalışmalarında yaygın olarak kullanılmaktadır. Yüksek pristan $(\mathrm{Pr})$ içeren numuneler oksitleyici, yüksek fitan $(\mathrm{Ph})$ içeriği ise redükleyici bir kaynağı yansıtmaktadır. Dolayısıyla, petrol veya bitümleri sınıflandırmak için $\mathrm{Pr} / \mathrm{nC} 17$ 'nin $\mathrm{Ph} / \mathrm{nC} 18$ 'e karşı çizildiği diyagramlar kullanılmaktadır (Hunt, 1995). $\mathrm{Pr} / \mathrm{Ph}$ oranının 1.5 üzerinde olması, standart jeokimyasal yorumlamaya göre oksijenli bir ortamdaki çökelme koşullarına işaret etmekle birlikte, $\mathrm{Pr} / \mathrm{Ph}$ oranlarının anoksik çökelme ortamları için 1'in üzerinde olabileceği de iyi bilinmektedir. Daha düşük değerler, aynı sekansın diğer bölümlerine kıyasla daha az oksik koşulları gösterebilir (Hartkopf-Fröder ve diğ., 2007). İzoprenoid/n-alkan oranı, kırılma ile kerojenden daha çok n-alkan serbest kaldığı için olgunluğun artması ile azalmakta olup (Tissot ve Welte, 1984; Hunt, 1995) biyolojik bozunmaya uğramamış petrol ve bitüm örnekleri için olgunluğun bir ölçütü olarak kullanılmaktadır. $\mathrm{Bu}$ oran, n-alkanların daha kolay yok olmasından dolayı biyolojik bozunma ile artmakta (Hunt, 1995), organik madde girdisi ve ikincil işlevler tarafindan da etkilenmektedir. İncelenen su numunelerinin $\mathrm{Pr} / \mathrm{nC} 17$ - $\mathrm{Ph} / \mathrm{nC} 18$ diyagramındaki konumlarına göre, hidrokarbonları türeten kaynak kayanın denizel kuvvetli redüksiyon (Tip II kerojen) ve geçiş ortamında (Tip II-III kerojen) çökeldiği ve hidrokarbonların olgun seviyede oldukları görülmektedir (Şekil 8, 9 ve 10). $\mathrm{Pr} / \mathrm{Ph}$ ve $(\mathrm{Pr}+\mathrm{Ph}) /(\mathrm{nC} 17+\mathrm{nC18}$ ) diyagramı da (Şekil 11), oksiklik veya anoksiklik artışı hakkında bilgi sağlamaktadır (Hartkopf-Fröder ve diğ., 2007).

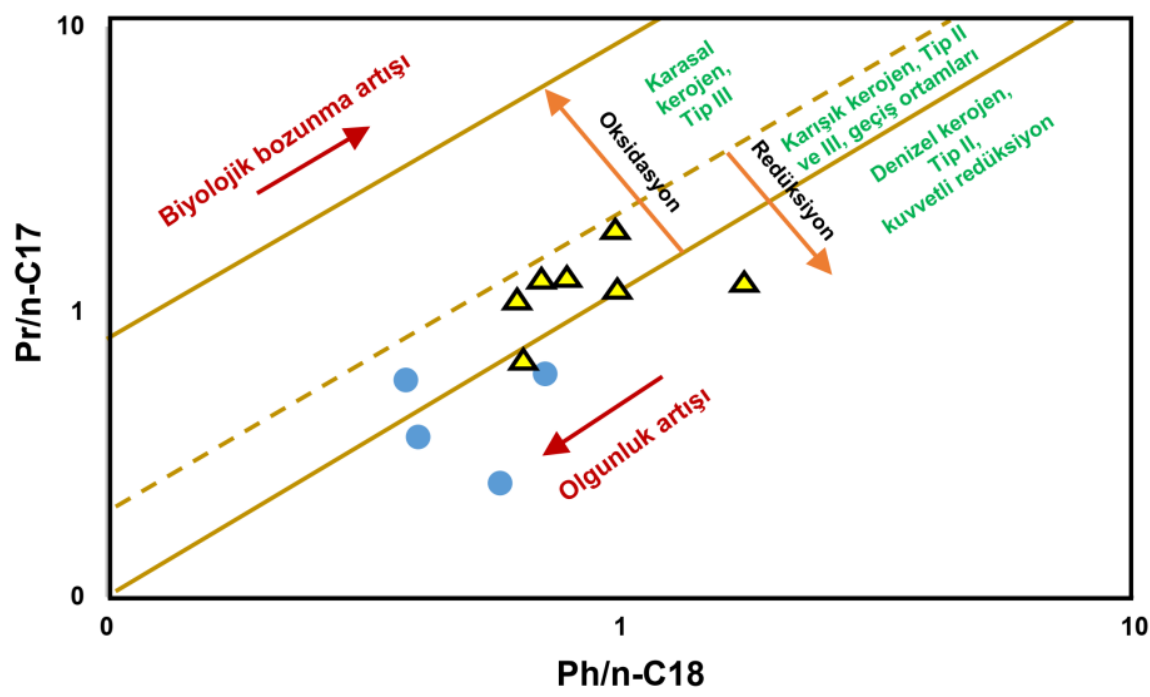

Şekil 8. İncelenen su numunelerinin Pr/n-C17-Ph/n-C18 diyagramı (Peters ve diğ., 1999). Mavi renkli daireler: Mamak (Ankara) numuneleri, sarı renkli üçgenler: Hasanoğlan (Ankara) numuneleri (bkz. Şekil 2; Özdemir, 2019a) 


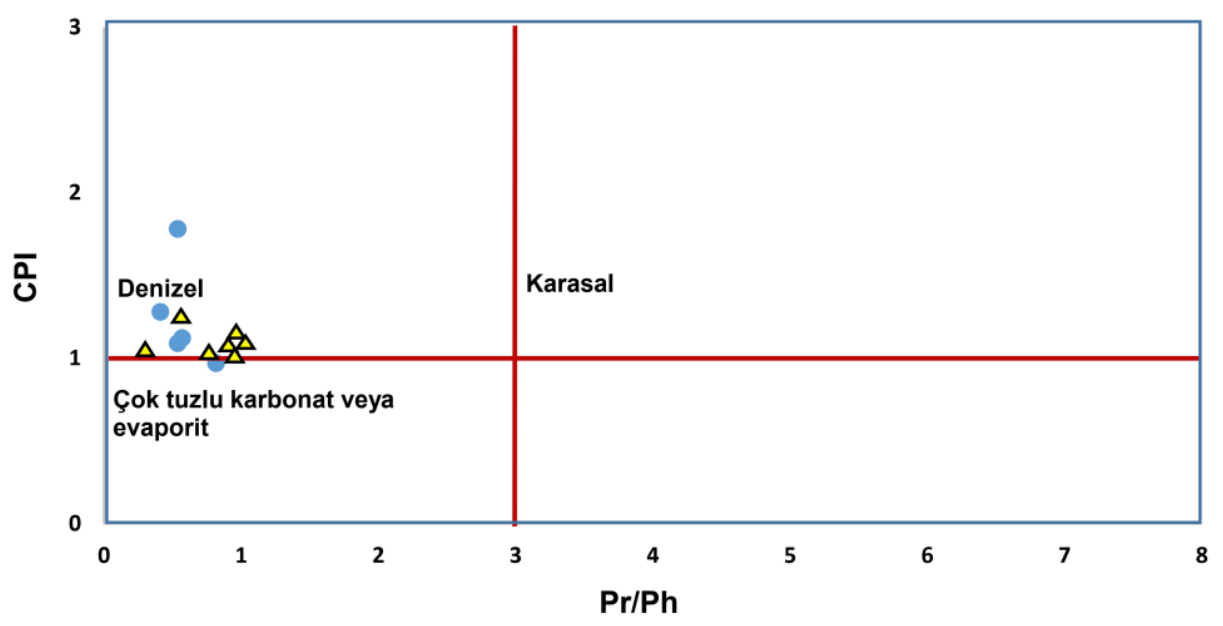

Şekil 9. Su numunelerinin Pr/Ph - CPI diyagramı (Hakimi ve diğ., 2017). Mavi renkli daireler: Mamak (Ankara) numuneleri, sarı renkli üçgenler: Hasanoğlan (Ankara) numuneleri (bkz. Şekil 2; Özdemir, 2019a)

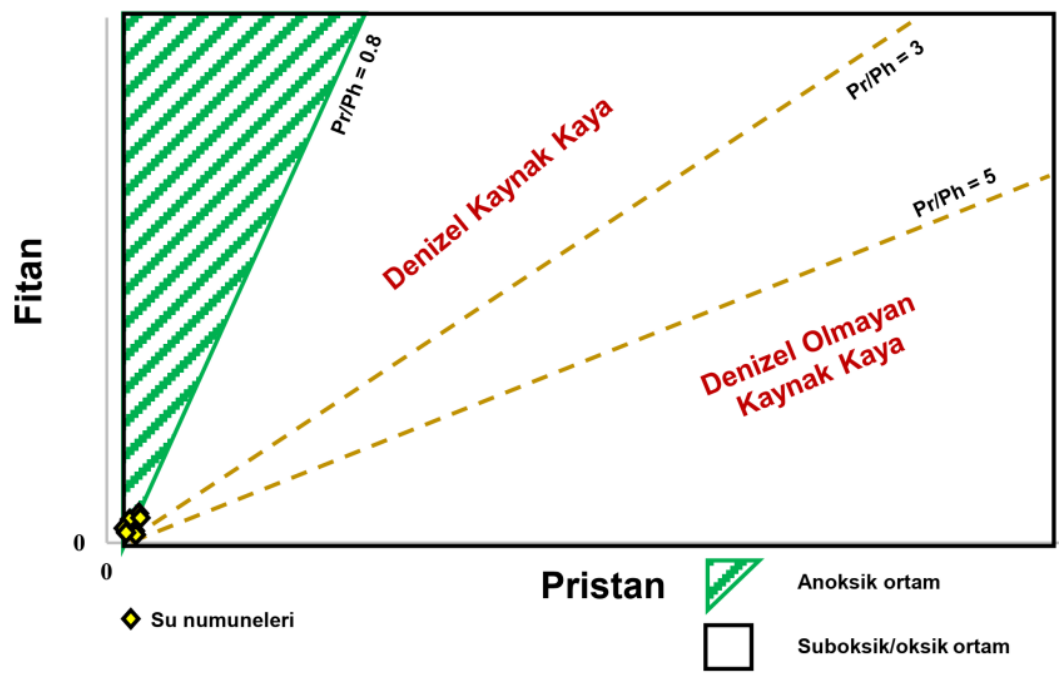

Şekil 10. Mamak ve Hasanoğlan su numunelerinin Fitan (Ph)/Pristan (Pr) diyagramı (Banga ve diğ., 2011)

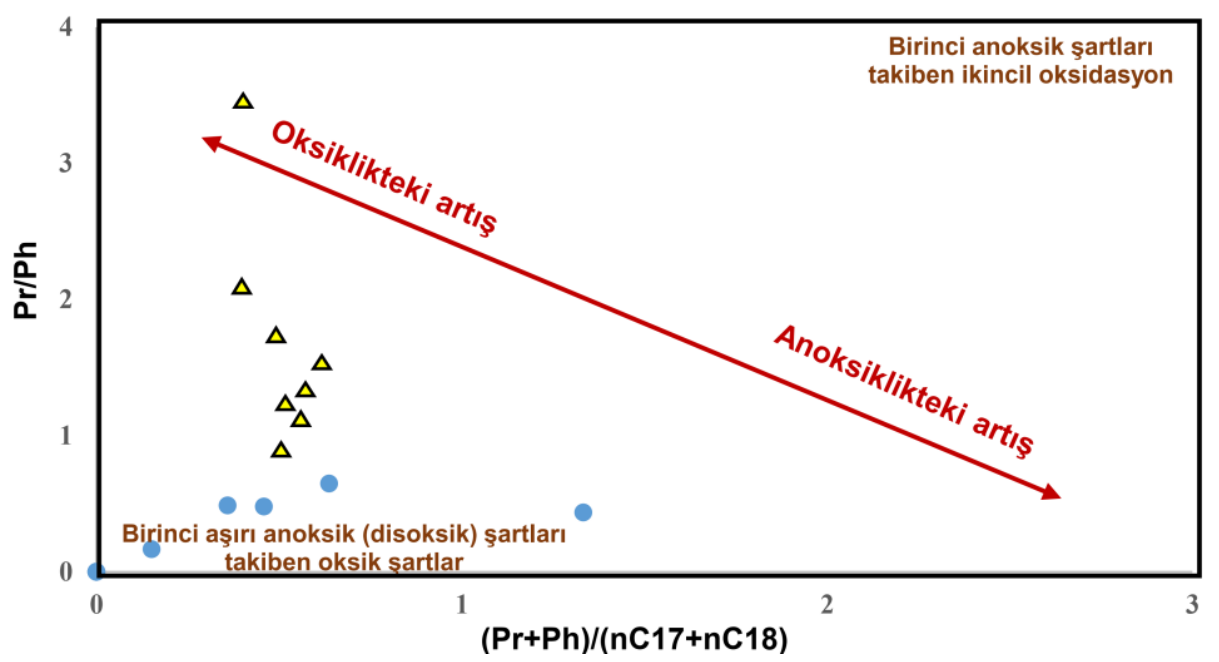

Şekil 11. Su numunelerinin $(P r+P h) /(n C 17+n C 18)$ diyagramı (Frimmel ve diğ., 2004). Mavi renkli daireler: Mamak (Ankara) numuneleri, sarı renkli üçgenler: Hasanoğlan (Ankara) numuneleri (bkz. Şekil 2; Özdemir, 2019a)

Her bir Tetis okyanusunun açılması (Prototetis, Paleotetis, Neotetis), kıtaiçi riftleri meydana getiren gerilme tektoniği eşliğinde olmuştur. Bu rift havzaları, bölgedeki petrol oluşumu için uygun alanlar olarak kabul edilmektedir. Bu tektonik-sedimantasyon sistemi, Tetis bölgesine özgü biçimleri ile petrol oluşumu ve birikimi üzerinde etkili olmuştur (Ulmishek ve Klemme, 1990; Sorkhabi, 2010). Genellikle, pasif kıta kenarları boyunca görülen riftleşme esnasında meydana gelen sedimanter havzalara rift havzası 
denilmektedir. Bu tür havzalar, organik maddece zengin bol miktarda kırıntılı kaya içerirler. Rift havzaları, oluşumları sırasında yatay çekme ve dikey çökmenin etkisi altındadır. Bir rift sisteminin ve okyanus açılması üç safhada incelenebilir (Şekil 12); 1. Rift öncesi, 2. Riftleşme, 3 Açılma safhaları. Birinci safhada (rift öncesi), bölgedeki çekilme (genişleme) giderek artarken bölgede sığ karasal ortamların hakimiyeti görülür. İkinci safhada (riftleşme), çökelme hızlı bir şekilde artar ve havzalarda gölsel sedimantasyon başlar. Son safhada ise (açılma safhası), okyanus kabuğu oluşurken bölge deniz suları ile kaplanır. Ancak, su basması rift sisteminin ekseninden başladığı için sistemin kenarındaki havzalarda sadece karasal çökellere rastlanırken, merkeze doğru bunun üzerine geçiş ve denizel ortamlara ait çökellerin geldiği görülmektedir (Şekil 12). Bu ve benzeri jeokimyasal nedenlerle kenardaki havzalarda sadece gaz, merkezi havzalarda ise petrol bulma olasılığı daha yüksektir. Rift havzalarının kaynak kayalarında oluşan petrolün, genellikle yakın mesafeli bir taşınma ile rezervuar kayaya göç etmesi beklenir. Rift havzalarındaki yoğun tektonik faaliyet ve yaygın fasiyes değişimleri nedeniyle, çok sayıda stratigrafik ve yapısal kapanlar vardır. Sadece karasal çökelleri içeren rift sistemlerindeki havzalar, sadece gaz oluşumu için uygundur. Pasif kıta kenarları boyunca oluşan okyanus şelfinde ve daha genç sedimanlarla örtülmüş rift havzaları petrol aramalarına uygundur. Rift havzası çökelleri, organik karbon içeriği açısından önemlidir. Triyas yaşlı rift havzaları, yerkabuğundaki toplam organik karbonun \%14'ünü içermektedir (Ediger, 1987). Türkiye kuzeyinde geniş dağılımı sahip olan Karakaya karmaşığının tektonik gelişimini açıklayan rift modelinde (Okay ve Göncüoğlu, 2004), Karakaya karmaşığı kayalarının Üst Permiyen yaşlı bir riftte oluştuğu ve bu riftin daha sonra okyanusal bir kenar denizine dönüştüğü ve Üst Triyas'ta kapandığı belirtilmiştir. Orta-Geç Triyas'ta Karakaya okyanus tabanında gerilmeli bir rejimin (okyanus ortası sırt) kurulduğu ve sistemin muhtemel olarak alt mantodan kaynaklanan tüketilmemiş karakterde magmalardan katkı aldığı yani bir manto sorgucunun varlığını gösterdiği belirtilmiştir (Sayit ve diğ., 2010). Karakaya karmaşı̆̆ında petrol kaynak kayası oluşumu için Şekil 13'deki model önerilmiştir (Özdemir, 2019a). Triyas, Neotetis'in açılmasını, pasif kıta kenarı çöküşünü ve Kuzey Arabistan'da yay gerisi riftleşmesi ve sonunda da Akdeniz'deki riftleşmenin başlangıcı olarak tanımlanmaktadır. Bu süreçler, Kimmeriyen orojenezi ve Paleotetis okyanus güneyinde Neotetis okyanusunun açılmasına sebep olmuştur (Şekil 14). Permiyen-Triyas sınırı, levha ölçeğinde bir uyumsuzluk oluşturur. Triyas, daha az miktarda geçiş ortamı denizel şeyllerle, baskın olarak dolomitik ve evaporitlerle ardalanmalı sığ denizel karbonatlar ve fluviyal-deltaik sı ̆ denizel silisiklastiklerden ve yerel olarak volkaniklerden oluşmaktadır. Triyas yaşlı kaynak kayalar, ağırlıklı olarak geçiş ortamı denizel karbonatları / dolomitleri ve evaporitlerdir (Kendal ve diğ., 2014).

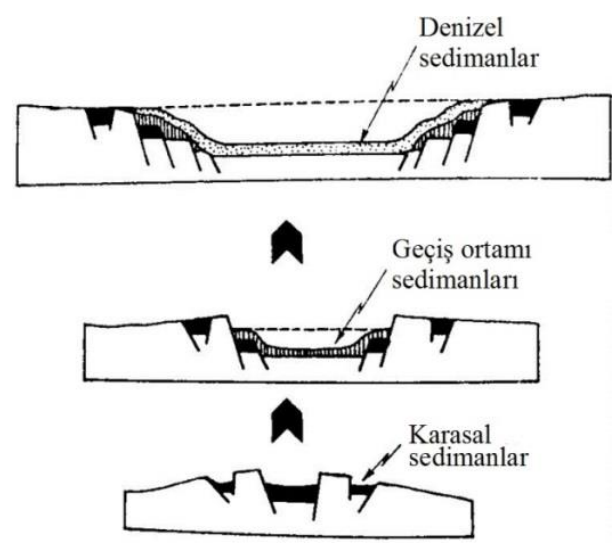

Şekil 12. Pasif kıta kenarı kenarları boyunca oluşan rift havzalarında karasal, geçiş ortamı ve denizel sedimanların birikimi (Ediger, 1987)

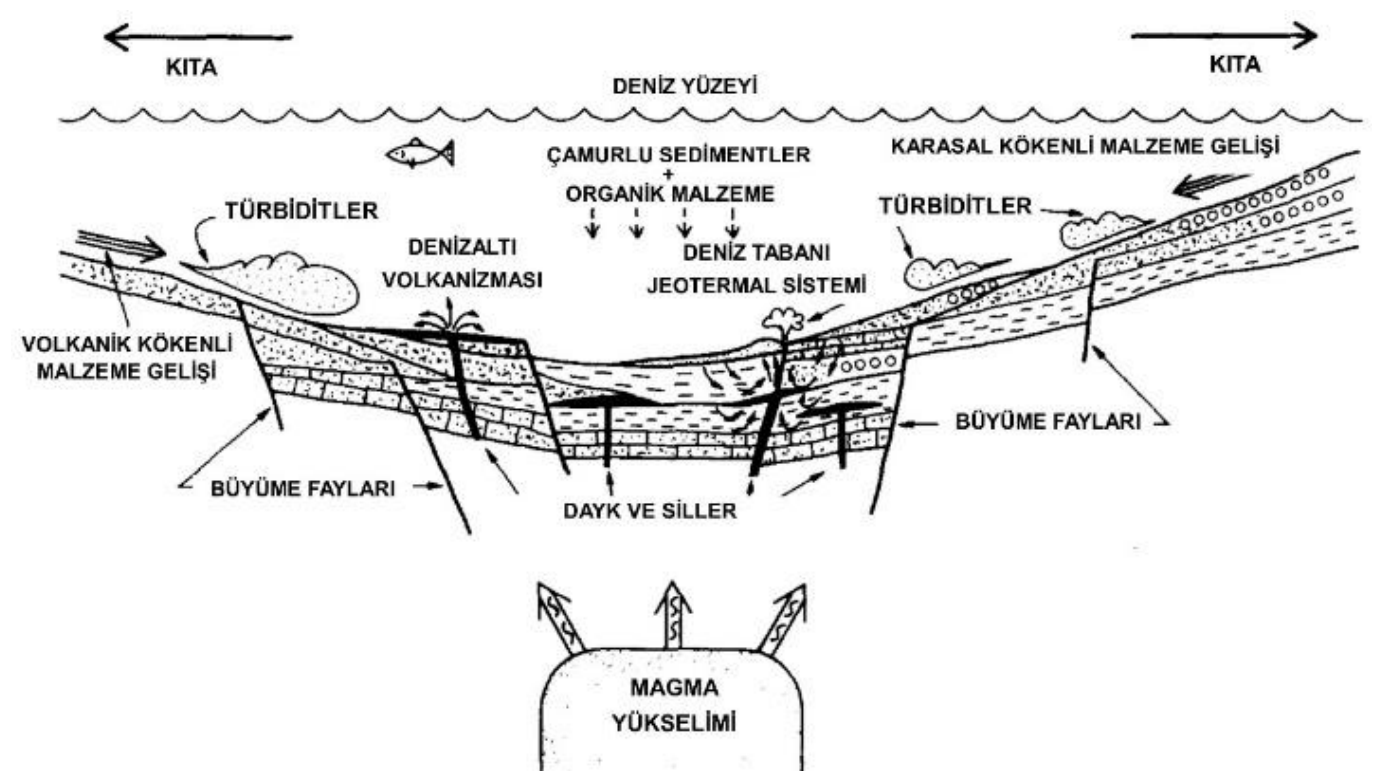

Şekil 13. Bir rift sisteminde petrol kaynak kayası oluşumunun kavramsal modeli (Özdemir, 2019a) 


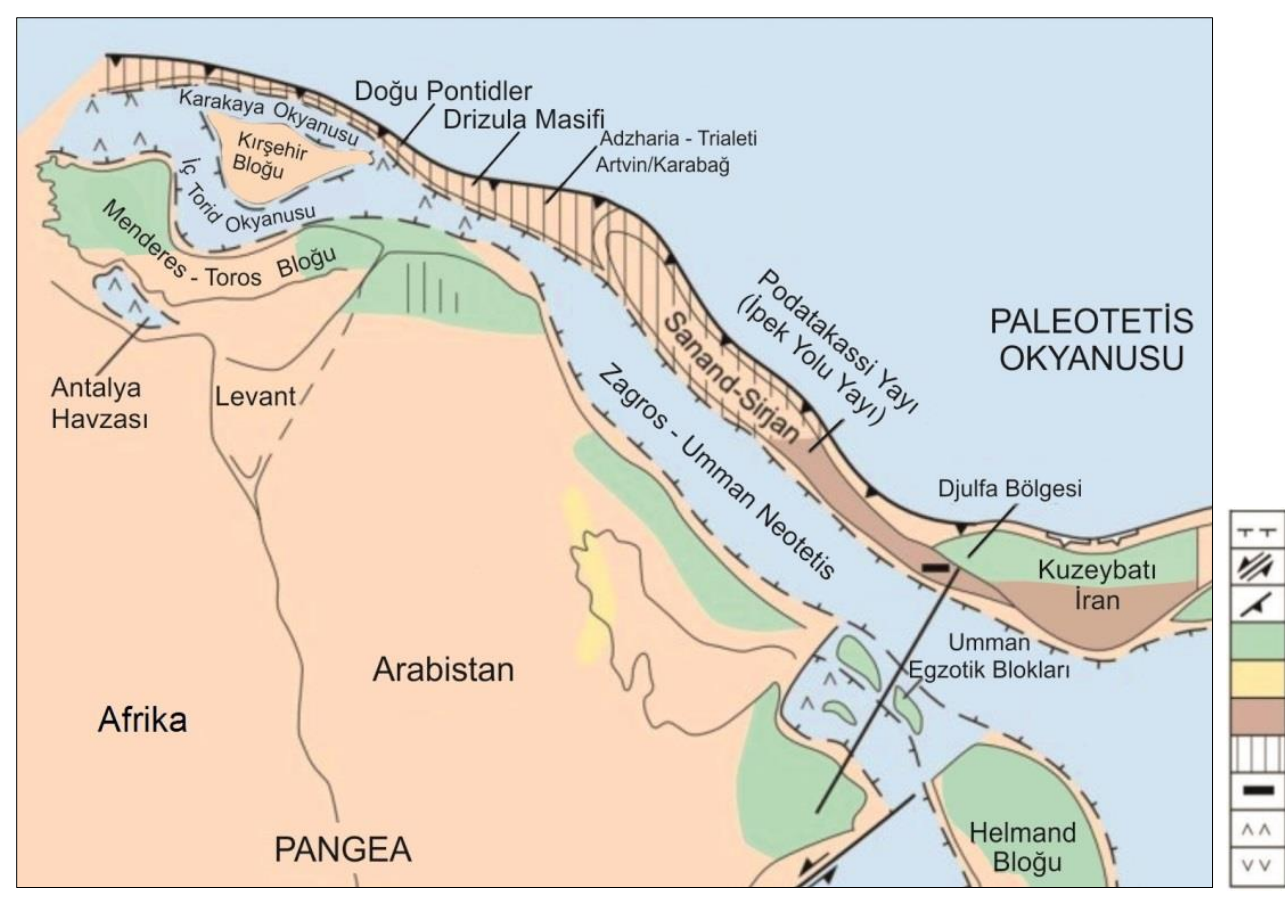

Riftli kıta kenarı

Doğrultu atımlı fay

Dalma-batma zonu (dișler üst levhada)

Karbonat

Kumtaşı

Şeyl

Erozyon bölgesi

Mafik tabakalı sokulumlar (sikhiron)

Rift volkanizması

Yay volkanizması

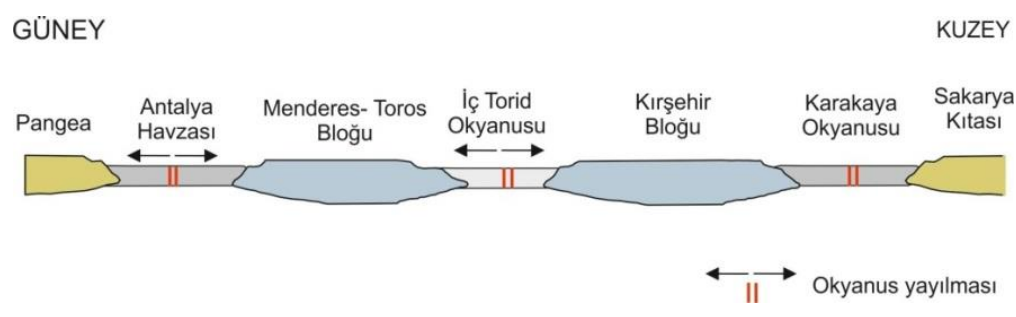

Şekil 14. Türkiye 'nin Alt Triyas paleocoğrafyası (Ruban ve diğ., 2007'den değişstirilerek)

Organik jeokimyasal analizler, hem optik hem de kimyasal yöntemleri içerir (Tissot ve Welte, 1984). Bir analitik yöntem, kesin sonuç elde etmek için yeterli olmayabilir. Genellikle, en güvenilir 2 veya 3 yöntem birlikte kullanılır. Bu yöntemlerden elde edilen veriler [1: organik maddenin petrol veya gaz zenginliğinin miktarı, 2: organik maddenin petrol veya gaz eğilimi ve 3: olgunluk seviyesi (düşük olgun, olgunlaşmış veya yüksek olgun-metamorfize)], birbirleri ile ilişkilendirilir (Hunt, 1995). Termal olgunlaşma belirteçlerinin ilişkilendirilmesi Şekil 15'de, incelenen su numunelerindeki hidrokarbonları türeten organik madde (kerojen) tipi, hidrokarbonların termal olgunluk durumları ve hidrokarbon türü de Tablo 4'de verilmiştir. Bu değerlendirmeye göre, incelenen su numunelerindeki hidrokarbonların bir kısmı düşük olgun ve çoğunluğu olgun olup, diyajenetik olarak kısmen diyajenez (erken kuru gaz), baskın olarak katajenez ve metajenez aşamasındaki kuru, kondenseyt ve ıslak gaz, hafif ve ağır ve petroldür (Tablo 4).

\section{3. İnceleme Alanının Havadan Manyetik ve Gravite Haritalarının Jeolojik Yorumu ve Yapı Derinliği}

İnceleme alanında olduğu gibi, jeokimyasal araştırmalarla petrol hidrokarbonları varlığı kanıtlanmış (olgun hidrokarbonlarca zengin sular belirlenmiş) olan bölgelerdeki petrol ve/veya doğalgaz rezervuarının (kapanının) yerinin belirlenmesi için özellikle sismik ölçümler çok önemlidir. Ancak, çalışma alanında değerlendirmeye esas olabilecek sismik ölçüm hatları bulunmamaktadır. Bu nedenle, çalışma alanının yeraltı jeolojisi MTA Genel Müdürlüğü tarafından üretilmiş olan gravite ve manyetik verilerden hazırlanan haritalar kullanılarak değerlendirilmiş ve yorumlanmıştır.

Gravite ve manyetik verilerinin petrol ve doğalgaz aramalarında kullanımına yönelik yöntemleri ve saha uygulamalarını içeren çok sayıda çalı̧̧ma mevcuttur (bazı çalışmalar; Özdemir, 2019a,b; Özdemir ve Şahinoğlu, 2018; Gadirov ve diğ., 2018; Stephen ve Iduma, 2018; Satyana, 2015; Ivakhnenko ve diğ., 2015; Gadirov ve Eppelbaum, 2012; Aydın, 1997, 2004; Pašteka, 2000; Piskarev ve Tchernyshev, 1997; Gadirov, 1994; Lyatsky ve diğ., 1992; Geist ve diğ., 1987; Nettleton, 1976; Griffin, 1949). Gravite ve manyetik anomali analizi, Batı Sibirya'da hidrokarbon arama ve keşfinin yarım yüzyıldan bugüne kalıcı bir bileşeni olmuştur. Kuzey Batı Sibirya'nın petrol ve doğalgaz yatakları çoğunlukla, derin riftojenik yapılardan kaynaklanan pozitif bölgesel gravite ve manyetik anomalilerin yamaçlarında yer almaktadır. Bilinen tüm petrol ve doğalgaz yatakları, nispeten yüksek gravite anomalileri ile karakterize olan bölgelerdedir. Hem gravite hem de manyetik anomalinin pozitif (yüksek gravite ve manyetik) olduğu bir alan riftojenik bir yapıya işaret eder. Bu pozitif anomalinin, bazik-ultrabazik kayaçlardan kaynaklandığı kabul edilmektedir. Petrol ve doğalgaz sahaları, bu pozitif anomalinin kenarında veya yakın çevresinde bulunurlar. Aynı zamanda, temel kayaçların yoğunluğu ve manyetizmasındaki düşüşler nedeniyle oluşan gravite ve manyetik değerlerin birlikte düşük olduğu alanlarda da petrol ve doğalgaz yataklarına rastlanılmıştır. İkincil alterasyon etkisine maruz kalmış temel kayaçların gravite ve manyetik değerlerinin normal değerlerinden daha düşük olduğu da sıkça karşılaşılan bir durumdur. Yoğunluğu ve manyetik özellikleri düşük temel üzerindeki petrol 
ve doğalgaz sahaları, başlıca negatif gravite ve manyetik anomali konturları içerisinde, yani düşük graviteli ve manyetizmalı alanlarda bulunurlar. Bu durumda oluşan negatif anomaliler, epijenetik süreçlerin petrol ve doğalgaz yataklarının oluşumunda önemli bir rol oynadığı görüşü ile de uyumludur (Piskarev ve Tchernyshev, 1997).

Hazırlanan havadan manyetik haritada (Şekil 16), mavi, yeşil ve açık yeşil renkli alanlarda manyetik özelliği olmayan tamamen sedimanter (kumtaşı, kireçtaşı, silttaşı, çamurtaşı, kiltaşı, çakıltaşı, şeyl vb.) ve metamorfik (kristalize kireçtaşı, mermer, kuvarsit, şist vb.) kayaçlar bulunmaktadır. Sarı, kırmızı ve beyaz renkli alanlarda ise, manyetik özelliği olan kayaçlar yer almaktadır (volkanik çakıllı kumtaşları, ofiyolitler, dayklar vb.) (Şekil 16).

Hazırlanan gravite haritasında (Şekil 17), düşük yoğunluklu sedimanter kökenli kayaçlardan oluşan genç çökeller (silttaşı, çamurtaşı, kiltaşı, çakıltaşı, şeyl vb.) ve metamorfik (sleyt, fillit vb.) koyu mavi, açık mavi ve yeşil renk tonları ile yoğunluğu nispeten daha büyük olan kayaçlar ise turuncu, kırmızı ve sarı renk tonları ile temsil edilen yoğunluğu nispeten yüksek kayaçlardan (kristalize kireçtaşı, mermer, kuvarsit, şist vb.) kaynaklanan bir anomali yer almıştır (Şekil 17).

Olgun hidrokarbonlarca zengin su numuneleri, çalışma alanında çalışan bir petrol sistemi için önemli bir kanıttır. Birbirleriyle oldukça uyumlu olan gravite ve manyetik haritaları ile belirlenen, baskın olarak GB-KD doğrultulu genişliği yaklaşık 20 km, eni 10 $\mathrm{km}$ olan hidrokarbonların kapanlanabileceği ve korunabileceği bindirme antiklinali, bölgedeki olası petrol ve/veya doğalgaz rezervuarıdır (Şekil 18). Yapının iki bindirme zonunu arasında olması, hidrokarbonların bu yapıda birikmiş olma ihtimalini kuvvetlendirmektedir.

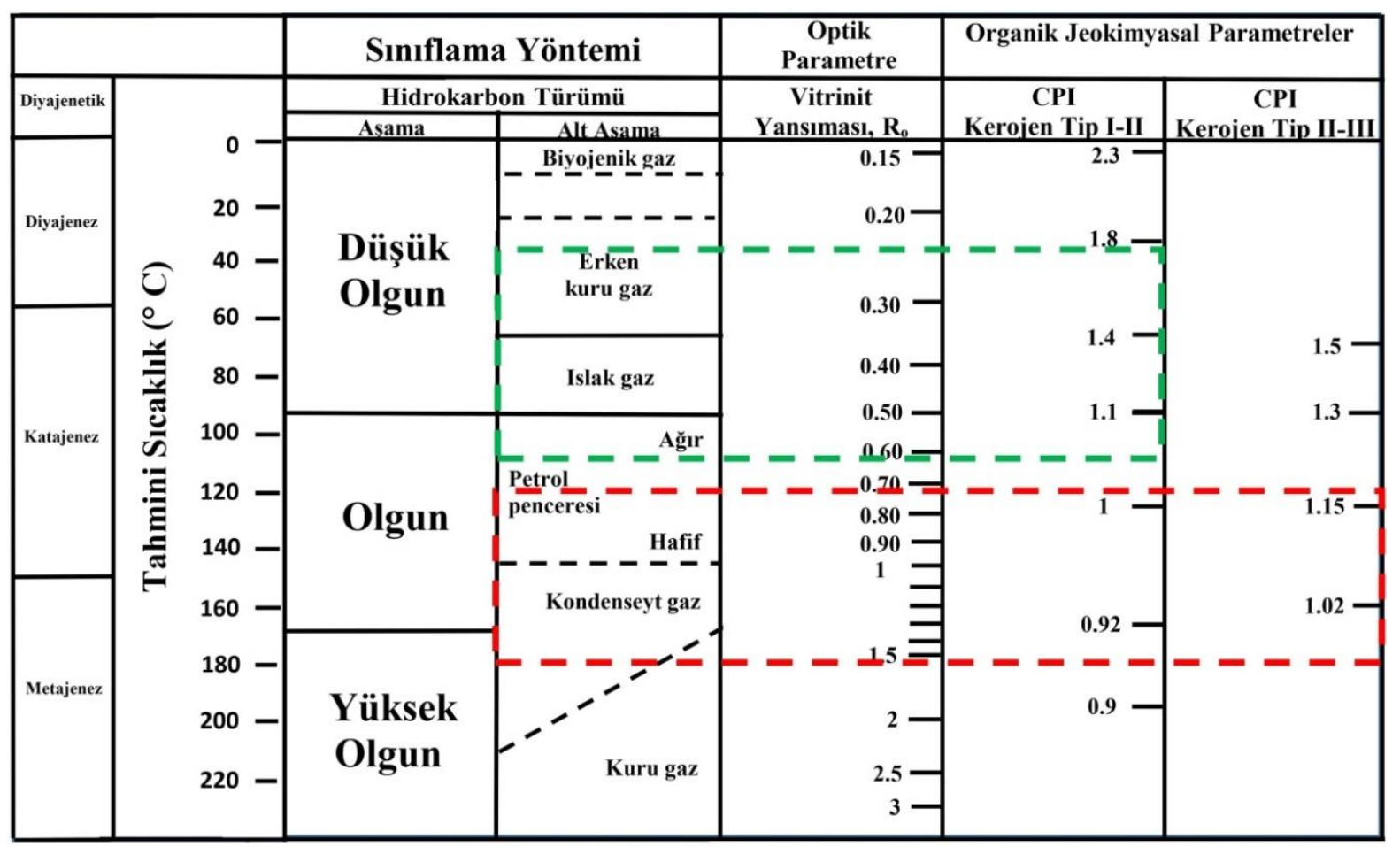

Sekil 15. Termal olgunlaşma belirteçlerinin, vitrinit yansıma $\left(R_{o}\right)$ ve Karbon Tercih İndeksi $(C P I)$ değerlerinin ilişkilendirilmesi (Thompson, 1982; Heroux ve diğ., 1979'den). Yeşil renkli çizgili alan:su numunelerindeki Tip II kerojenden türeyen hidrokarbonlar, kırmızı renkli çizgili alan: su numunelerindeki Tip II-III kerojenden türeyen hidrokarbonlar (bkz. Tablo 4)

Tablo 4. İncelenen su numunelerindeki hidrokarbonları türeten kerojen tipi, hidrokarbonların termal olgunluk durumlarl, hidrokarbonların tipi ve diyajenetik aşamast (bkz. Şekil 15)

\begin{tabular}{|c|c|c|c|c|c|c|}
\hline Lokasyon & $\begin{array}{c}\text { Numune } \\
\text { No }\end{array}$ & CPI & $\begin{array}{c}\text { Kerojen } \\
\text { Tipi }\end{array}$ & Olgunluk Durumu & Hidrokarbon Tipi & $\begin{array}{c}\text { Diyajenetik } \\
\text { aşama }\end{array}$ \\
\hline \multirow{4}{*}{ Mamak } & M1 & 1.12 & II & Olgun & Ağır petrol & Katajenez \\
\cline { 2 - 7 } & M2 & 1.78 & II & Düşük olgun & Erken kuru gaz & Diyajenez \\
\cline { 2 - 7 } & M3 & 1.28 & II & Düşük olgun & Islak gaz & Katajenez \\
\cline { 2 - 7 } & M4 & 1.09 & II-III & Olgun & Hafif petrol & Katajenez \\
\cline { 2 - 7 } & M5 & 0.97 & II-III & Olgun & Kondenseyt gaz - kuru gaz & Metajenez \\
\hline \multirow{5}{*}{ Hasanoğlan } & H1 & 1.25 & II & Düşük olgun & Islak gaz & Katajenez \\
\cline { 2 - 7 } & H2 & 1.01 & II-III & Olgun & Kondenseyt gaz - kuru gaz & Metajenez \\
\cline { 2 - 7 } & H4 & 1.08 & II-III & Olgun & Hafif petrol & Katajenez \\
\cline { 2 - 7 } & H5 & 1.06 & II & Olgun & Ağır petrol & Katajenez \\
\cline { 2 - 7 } & H6 & 1.17 & II-III & Olgun & Hafif petrol & Katajenez \\
\cline { 2 - 7 } & H7 & 1.05 & II-III & Olgun & Hafif petrol - kondenseyt gaz & Metajenez \\
\cline { 2 - 7 } & H8 & 1.07 & II-III & Olgun & Hafif petrol & Katajenez \\
\hline
\end{tabular}



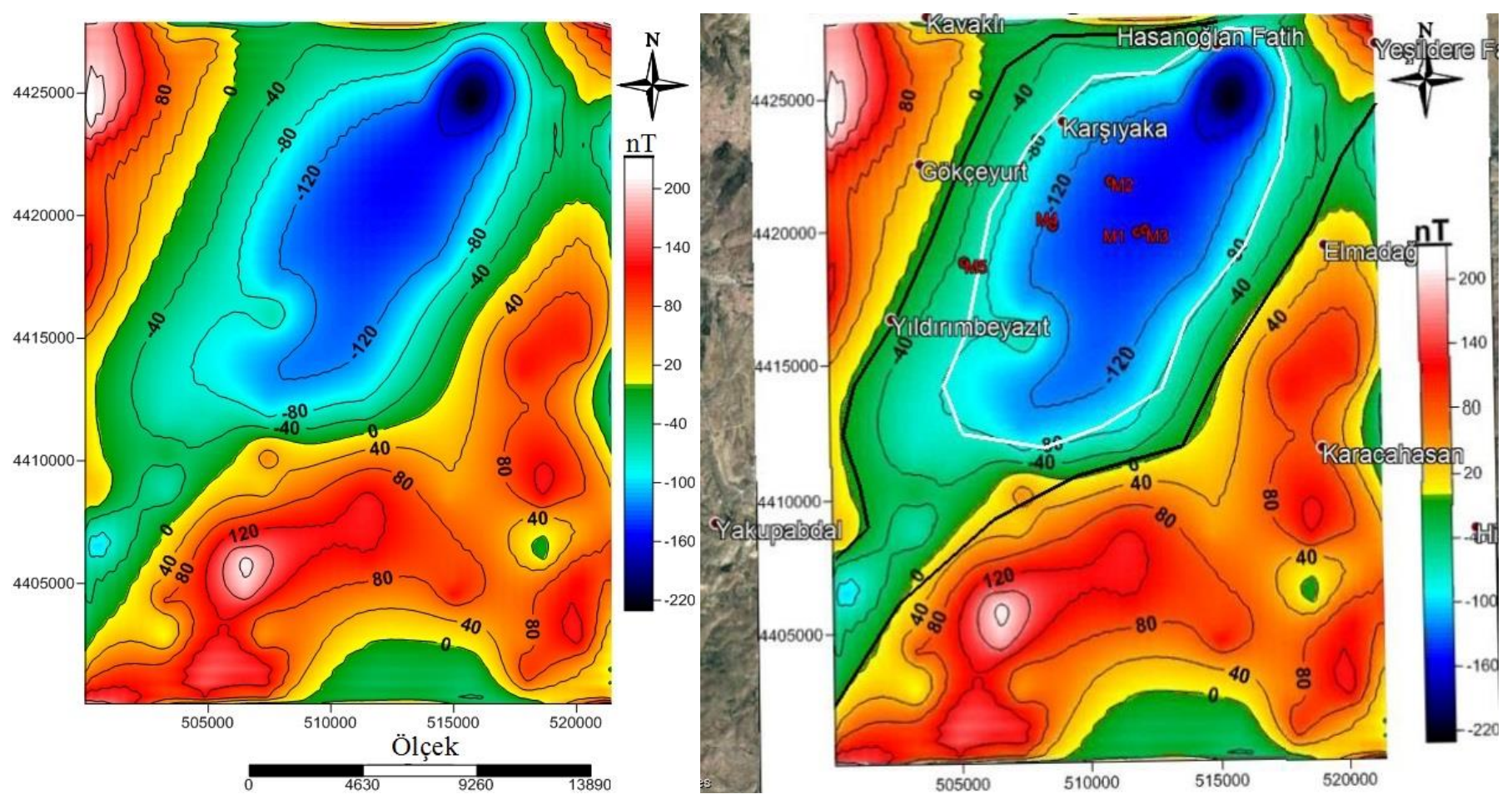

Sekil 16. Inceleme alanının havadan manyetik anomalileri renk kontur haritası. Petrol hidrokarbonları içeren su numuneleri: kırmızı renkli rakamlı daireler, muhtemel petrol kapanı: beyaz renkle işaretlenmiş poligon, siyah renkli çizgiler: ana faylar
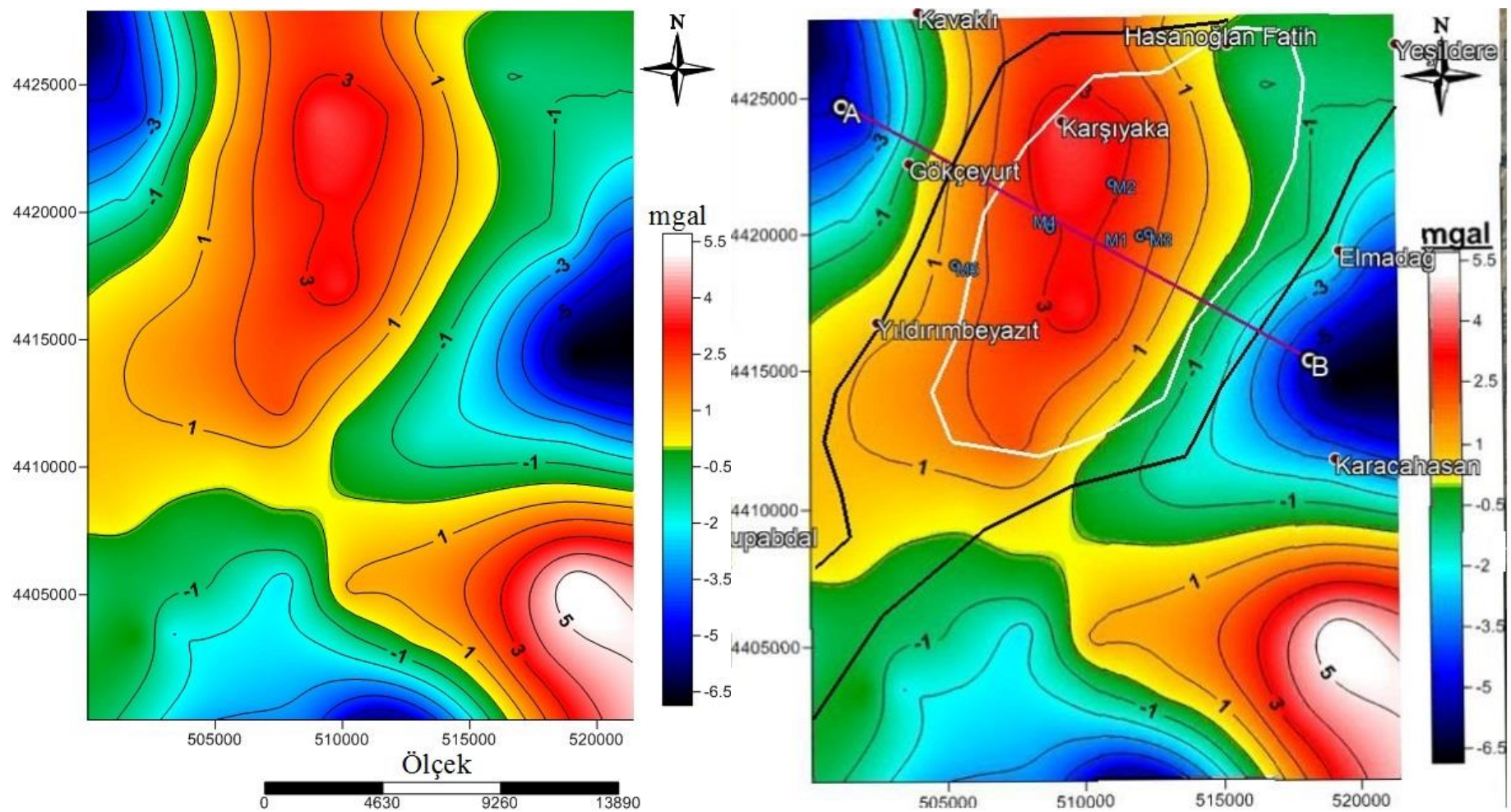

Sekil 17. Inceleme alanının gravite anomalileri renk kontur haritası. Petrol hidrokarbonları içeren su numuneleri: mavi renkli rakamlı daireler, muhtemel petrol kapanı: beyaz renkle işaretlenmiş poligon, siyah renkli çizgiler: ana faylar, A-B hattı: yapı derinliğini belirlemek için alınan profil

Çalışmada, iki boyutlu rezidüel gravite anomalilerini derinlik değerlerine dönüştürülebilmek ve havza ve yapı derinliklerini belirlemek amacıyla, Svancara (1983) ve Töpfer (1977) tarafından önerilen yorum yöntemi kullanılmıştır. Bu yöntemde, yoğunluk kontrastının bilinmesi durumunda gravite anomalisi ve parametreler arasında kurulan basit ilişkilerle sedimanter bir havza ve yapı derinliği belirlenebilmektedir. Yorumlamanın ilk adımı, anomalinin karakteristik parametrelerini belirlemektedir (Şekil 19). A = $\mathrm{g}_{\mathrm{mak}} / \mathrm{W}_{\mathrm{a}} \times \sigma$ şeklinde tanımlanır. $\mathrm{g}_{\mathrm{mak}}$ : gravite anomalisinin maksimum genliğidir. $\mathrm{W}_{\mathrm{a}}$ : gravite anomalisinin yarı genlik $\left(\mathrm{g}_{\mathrm{mak}} / 2\right)$ değerine karşılık gelen uzaklıktır. $\sigma$ : yoğunluk kontrastıdır. $\mathrm{W}_{\mathrm{b}}$ : gravite anomalisinin tam genişliğidir ve $\mathrm{W}_{\mathrm{b}} / \mathrm{W}_{\mathrm{a}}=(-0.056 \times \mathrm{A})+$ 
1.827 formülü ile belirlenir. $\mathrm{D}_{\mathrm{i}}, \mathrm{g}_{\mathrm{i}}$ : gravite anomali değerine karşılık gelen derinliktir. $\mathrm{D}_{\mathrm{o}}$ : düz-plaka formülünden elde edilen derinliktir. $\mathrm{D}_{\mathrm{o}}=23.866 \mathrm{x}$ g mak $/ \sigma$ formülü ile belirlenir ve birimi m'dir. $\mathrm{D}:$ maksimum derinliktir ve aşağıdaki formül ile belirlenir.

$0<\mathrm{A}<9$ şartı için $\mathrm{D} / \mathrm{D}_{\mathrm{o}}=0.072 \times \mathrm{A}+1.00$

$9<\mathrm{A}<13$ şartı için $\mathrm{D} / \mathrm{D}_{\mathrm{o}}=0.12 \times \mathrm{A}+0.57$ şeklindedir (Töpfer, 1977). Çalışma alanının rezidüel gravite anomali haritasından bir AB profili alınmıştır (Şekil 17). A-B profile ait anomalilere göre yapının maksimum derinliği (D) $=545.03 \mathrm{~m}$ olarak belirlenmiştir (Şekil 20).

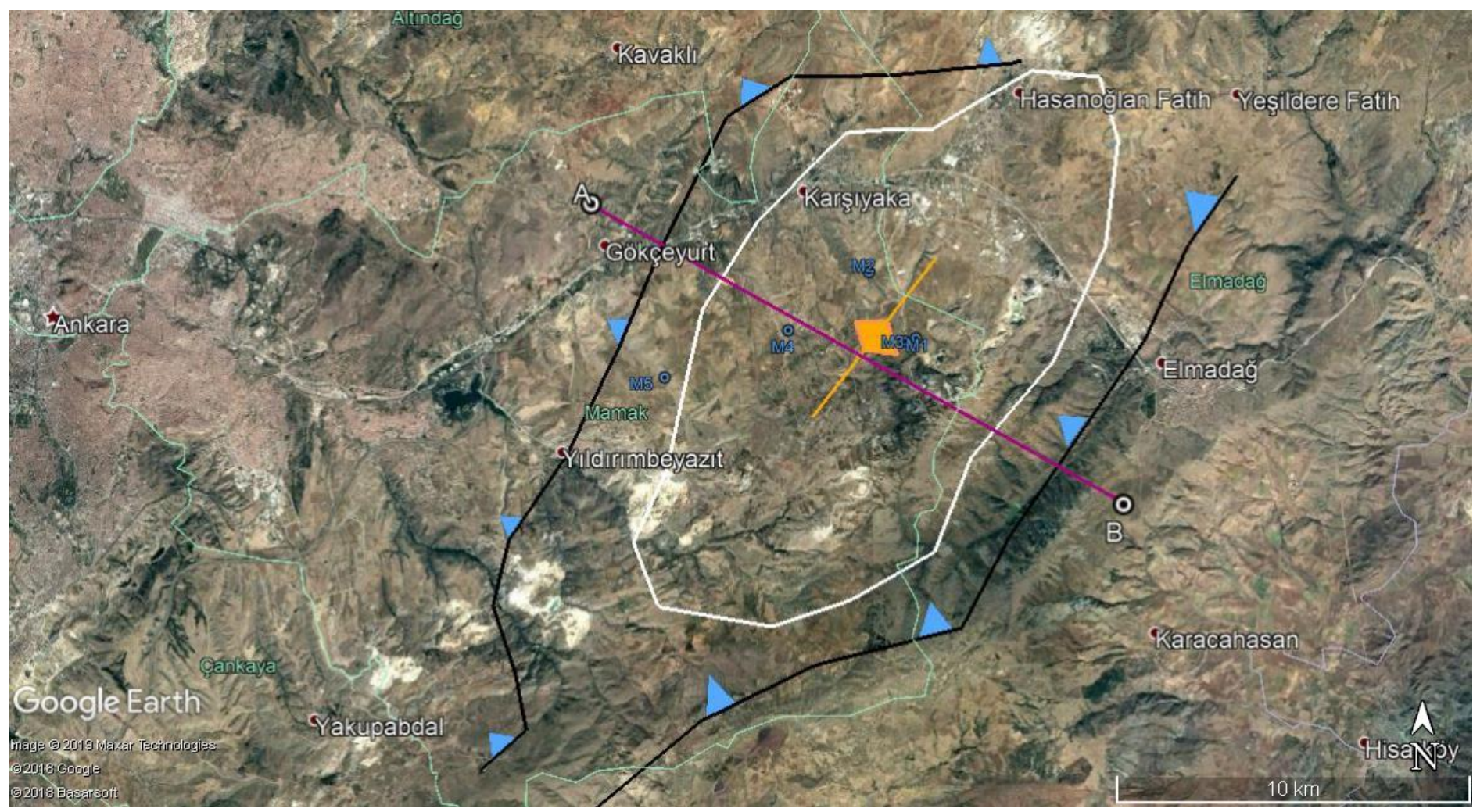

Şekil 18. İnceleme alanındaki potansiyel petrol ve/veya doğalgaz kapanı (beyaz renkli poligon). Olgun petrol hidrokarbonları içeren su numuneleri (mavi renkli rakaml daireler), tırnakl siyah renkli çizgiler: bindirme fayları (tırnaklar, bindiren birim üzerinde). A-B hattı: yapı derinliğini belirlemek için alınan profil (Şekil 20)

Olgun petrol hidrokarbonlarınca zengin yüzey ve yeraltı suları, hidrokarbon türeten etkin petrol kaynak kayaları ve yeraltındaki bir petrol ve/veya doğalgaz rezervuarı ile ilişkilidir. Derindeki kaynak kayalardan ve/veya rezervuardan yüzeye göç eden hidrokarbonca zengin sular, yüzeyde ve yüzeye yakın jeolojik ortamlarda (yüzey ve yeraltısularında) tanımlanabilir hidrokarbon konsantrasyonu değişikliklerine sebep olur (Özdemir, 2018). İncelenen su numunelerindeki hidrokarbonlar, derinlerdeki hidrokarbonca zengin jeolojik birimlerden su-kayaç-hidrokarbon etkileşimi sonucunda ve/veya gravite ve manyetik haritalarla belirlenen olası rezervuardan (Şekil 20) çıkan suların yüzeye/yüzeye yakın bölümlere göçüdür.

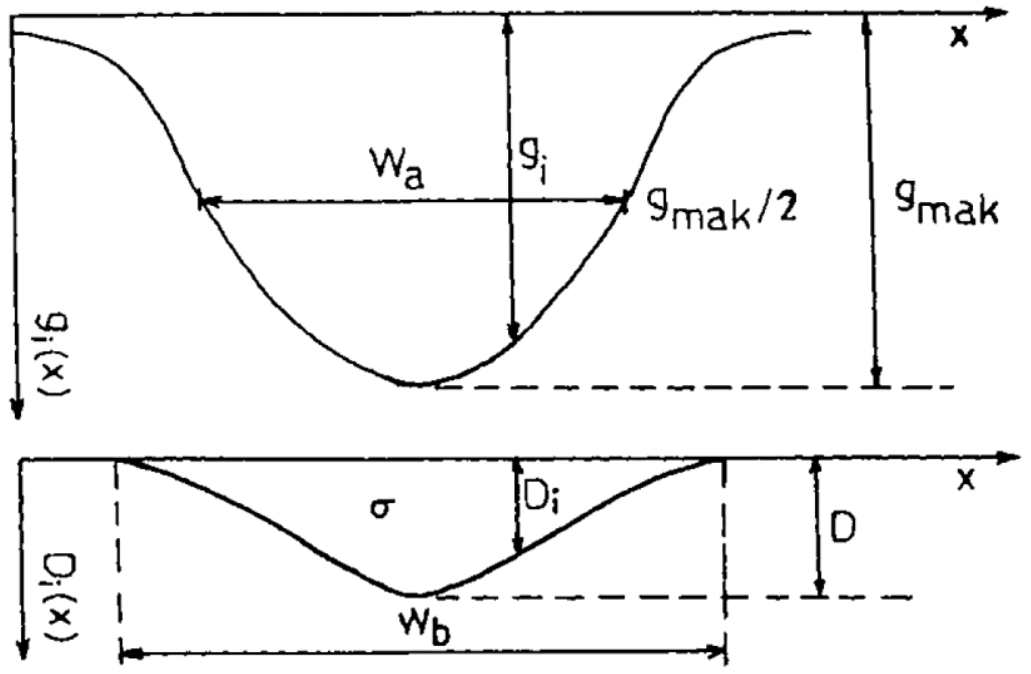

Şekil 19. İdeal bir havza gravite anomalisi ve karakteristik parametreler (Svancara, 1983) 


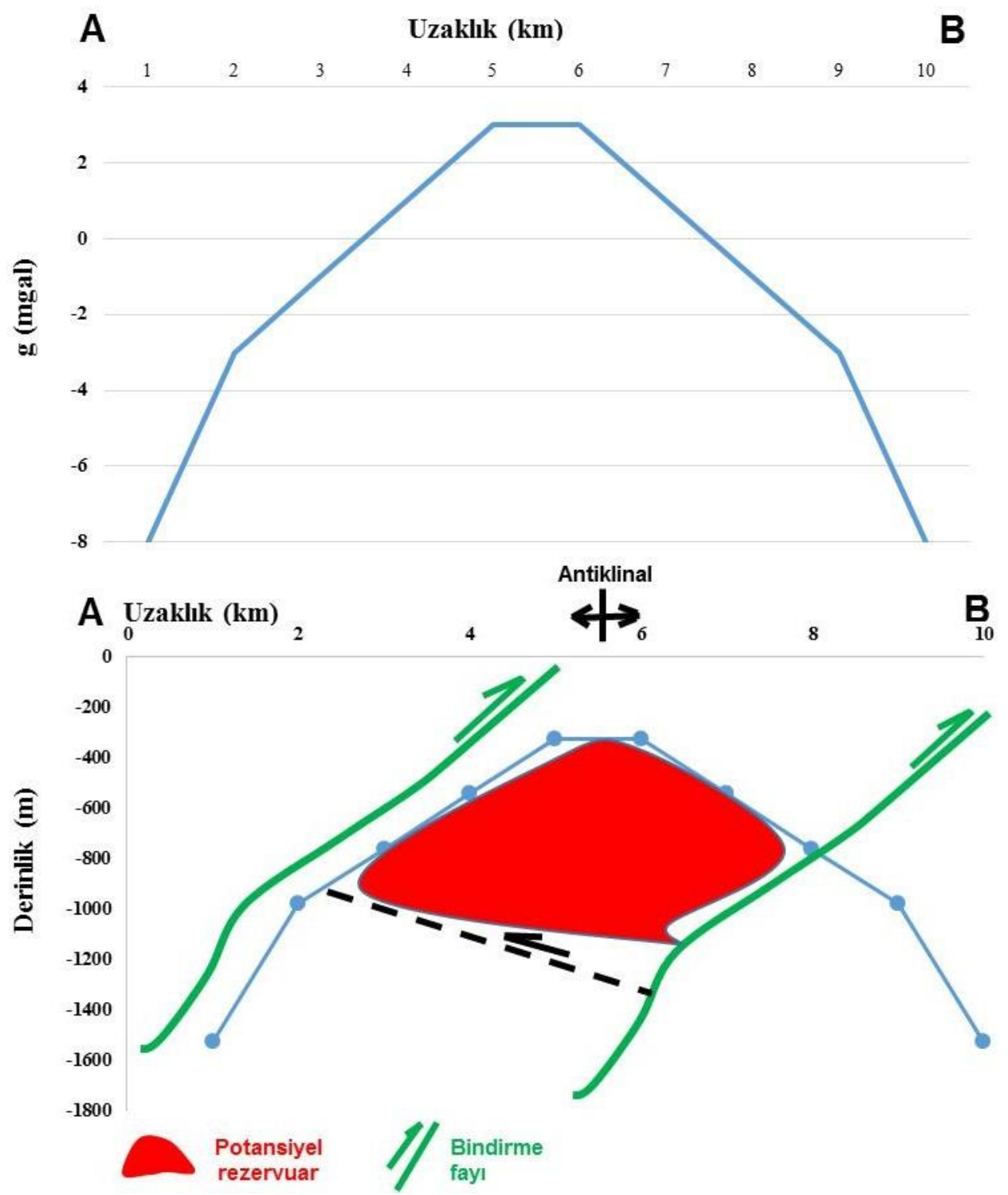

Şekil 20. A-B profilinin jeolojik yorumu ve inceleme alanındaki muhtemel petrol ve/veya doğalgaz kapanının derinliği (bkz. Şekil 17 ve 18)

\section{Sonuç ve Öneriler}

Çalışma alanından toplanan su numunelerinde yapılan suda petrol (TPH) analizi sonuçlarında, ham petrol kökenli n-alkan hidrokarbonlar tespit edilmiştir. Olgun hidrokarbonlarca zengin su numuneleri, bölgede çalışan bir petrol sisteminin varlığı için önemli bir kanıttır. Su numunelerindeki hidrokarbonları türeten kaynak kayalar denizel kuvvetli redüksiyon (Tip II kerojen) ve geçiş ortamında (Tip II-III kerojen) çökelmiştir. İncelenen su numunelerindeki hidrokarbonların bir kısmı düşük olgun ve çoğunluğu olgun olup, diyajenetik olarak kısmen diyajenez (erken kuru gaz), baskın olarak katajenez ve metajenez aşamasındaki kuru, kondenseyt ve sslak gaz, hafif ve ağır petroldür.

Hidrokarbonlarca zengin olan sular, gravite verilerine göre maksimum 330 m derinliğindeki kıvrımlı bir yapıdan fay ve kırıklar aracılığıyla yeryüzüne göç etmiş ve yüzeye yakın yeraltı suları ile karışmış olmalıdır. Bu kıvrımlı yapı, yaklaşı güneybatı-kuzeydoğu doğrultulu bindirmeler sonucunda oluşmuş bir antiklinaldir. Hidrokarbon içeren su numune lokasyonları, bu antiklinal yakınında ve üzerindedir.

Hazırlanan gravite ve manyetik haritalarla belirlenmiş olan yapının yapısal özelliklerini detaylı olarak belirlemek için, bu yapı üzerinde sismik, elektrik rezistivite, IP yöntemlerinden en az biri ile detay (hatlar-profiller arası sık olan) jeofizik çalışmalar yapılmalıdır. Jeofizik araştırma derinliğinin $1500 \mathrm{~m}$ dolayında seçilmesinin uygun olacağı düşünülmektedir. Çalışma alanı ve çevresindeki tüm su kaynaklarından (yüzey suları ve soğuk su kuyularından) numuneler alınarak TPH, ayrılabiliyorsa mutlaka BTEX (benzen, toluen, etilbenzen ve ksilen izomerleri) ve iyot analizleri yapılmalıdır. Ayrıca, su örneklerinde $\mathrm{Re}-\mathrm{Os}$, ${ }^{129} \mathrm{I},{ }^{13} \mathrm{C} /{ }^{12} \mathrm{C}\left(\delta^{13} \mathrm{C}\right)$ izotop analizleri yapılarak bölgede bu çalışma ile varlığı kanıtlanmış olan çalışan petrol sisteminin özellikleri (yaş, kaynak kaya, rezervuar kaya, örtü kaya vb.) tespit edilmelidir.

Hasanoğlan ve Mamak (Ankara) su numunelerindeki hidrokarbonlar, Permiyen-Triyas yaşlı Karakaya karmaşığı birimlerindeki çalışan petrol sistemleri için kanıttır. Bu hidrokarbonlar, büyük olasılıkla Permiyen-Triyas sınırındaki toplu canlı yokolması ile ilişkili 
olmalıdır. Bu veriler, Çanakkale'den Tunceli'ye kadar Türkiye kuzeyinde geniş bir yayılıma sahip olan Karakaya karmaşığı birimlerinde çalışan petrol sistemleri için önemli bir potansiyel bulunduğunu (Şekil 21), dolayısıyla bu birimlerde bu çalışmada kullanılan jeokimyasal analiz ve yorumlama yöntemleri esas alınarak detaylı jeolojik ve jeofizik arama çalışmalarının yapılmasının gerekliliğini ortaya çıkarmaktadır.

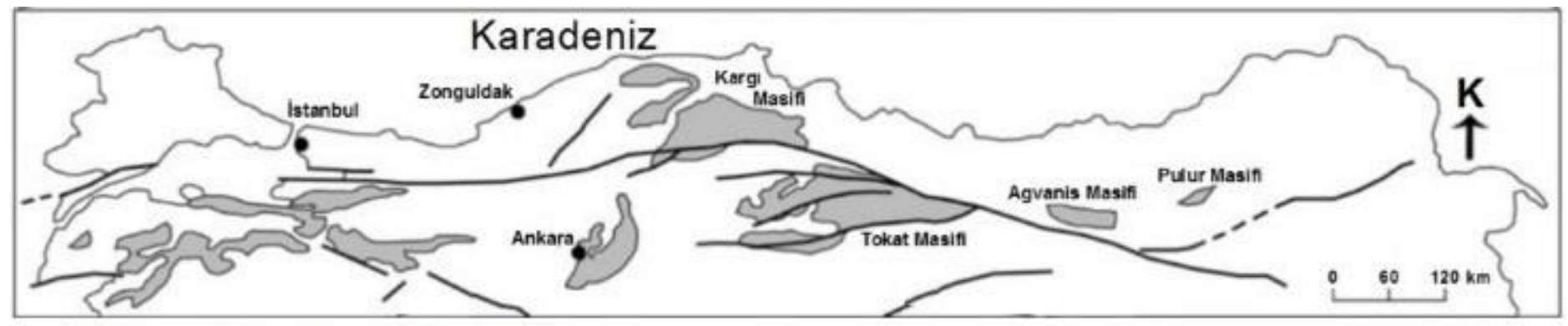

Permiyen-Triyas Karakaya karmaşı̆̆ı birimleri

Şekil 21. Karakaya karmaşı̆̆ının Türkiye kuzeyindeki dağılımı (Sayit, 2010)

\section{Teşekkür}

Yazar, çalışmaya geliştirici yönde görüşsel katkılar sunan Prof.Dr.Ergül YAŞAR'a (İskenderun Teknik Üniv. Petrol ve Doğalgaz Müh. Böl.) ve Doç.Dr.Orhan KAVAK'a (Dicle Üniv. Maden Müh. Böl.), su numuneleri alımı ve analizlerinin gerçekleşmesine olanak sağlayan DSİ Jeoteknik Hizmetler ve Yeraltısuları Dairesi Başkanı Jeo.Yük.Müh. Dr.Ayhan KOÇBAY'a, DSİ Hidrojeolojik Etütler Şube Müdürü Jeo.Yük.Müh. Mert TOKLU'ya, su numune analizlerine ekonomik destek sağlayan Fugro-Sial Yerbilimleri Mühendislik Ltd. Şti.'ne, numunelerin toplanmasında katkısı olan Jeo. Müh. Hüseyin Ertan YÜKSEL'e (Fugro-Sial Yerbilimleri Mühendislik Ltd. Şti.), analizleri titizlikle gerçekleştiren Türkiye Petrolleri (TPAO) Araştırma ve Geliştirme Merkezi uzmanlarına teşekkür etmeyi bir borç bilmektedir.

\section{Kaynakça}

Aydın, A., 1997. Gravite Verilerinin Normalize Edilmiş Tam Gradyan, Varyasyon ve İstatistik Yöntemleri ile Hidrokarbon Açısından Değerlendirilmesi, Model Çalışmalar ve Hasankale-Horasan (Erzurum) Havzasına Uygulanması. Karadeniz Teknik Üniversitesi, Doktora Tezi, $151 \mathrm{~s}$.

Aydın, A., 2004. Gravite anomalilerinin doğrudan yorum yöntemleri ile değerlendirilmesi: Hasankale-Horasan bölgesinden bir uygulama. Pamukkale Üniversitesi Mühendislik Bilimleri Dergisi, 11(1), 95-102

Banga, T., Capuano, R.M. and Bissada, K.K., 2011. Petroleum generation in the southeast Texas basin: Implications for hydrocarbon occurrence at the South Liberty salt dome. AAPG Bulletin, 95(7), 1257-1291

Beyer, J., Jonsson, G., Porte, C., Krahn, M.M. and Ariese, F., 2010. Analytical methods for determining metabolites of polycyclic aromatic hydrocarbon (PAH) pollutants in fish bile: a review. Environ. Toxicol Pharmacol, 30(3), 224-244

Bozkurt, E., 1990. Karakaya napı içinde yeni bir Karbonifer ve Permiyen bulgusu. MTA Dergisi, 110, 181-188

Bray, E.E. and Evans, E.D., 1961. Distribution of n-paraffins as a clue to recognition of source rocks. Geochim. Cosmochim, Acta. $22,2-15$

Bray, E.E. and Evans, E.D., 1965. Hydrocarbons in non-reservoir-rock source beds: Part 1. American Association of Petroleum Geologists Bulletin, 49, 248-257

Cai, C. F., Mei, B. W., Li, W. and Fan, G., 1997. Water-rock interaction in Tarim Basin: Constraints from oilfield water geochemistry. Chinese Journal of Geochemistry, 16, 289-303

Çelik, M., 1989. Ankara Doğu Kesiminin Mineralojik, Petrografik ve Jeokimyasal Özelliklerinin İncelenmesi. Hacettepe Üniversitesi, Fen Bilimleri Enstitüsü, Doktora Tezi, $253 \mathrm{~s}$.

Çorbacıoğlu, H., Kırman, Z.D., Yılmazer, P., Doğan, S., Tokoğlu, E.E., Araç, B., Türesin, F.M., Huvaj, N.Y., Elmacı, A., Türkecan, A.T., Çevik, T., Bahtiyar, İ., Sarıkaya, H., Aydın, MG., Bakırhan, B. ve Yüksel, M., 2018. Hakkâri-Yüksekova-Hisardağı Bölgesi'nden Alınan Su, Emare ve Kayaç Örneklerinin Değerlendirme Raporu. TPAO Rapor No: 4297

Didyk, B.M., Simoneit, B.R.T., Brassel, S.C. and Englington, G., 1978. Organic geochemical indicators of paleoenvironmental conditions of sedimentation. Nature, 272, 216-222

Ediger, V., 1987. Rift havzalarının jeoloik evrimi ve hidrokarbon potansiyeli. Türkiye 7. Petrol Kongresi, 1-10

Feng, Q.Y., and Han, B.P., 2002. Hydrogeochemical simulation of water-rock interaction under water flood recovery in Renqiu oilfield, Hebei Province, China. Chinese Journal of Geochemistry, 21, 156-162

Frimmel, A., Oschmann, W. and Schwark, L. 2004. Chemostratigraphy of the Posidonia Black Shale, SW Germany: I. Influence of sea-level variation on organic facies evolution. Chemical Geology, 206, 199-230

Gadirov, V.G., Eppelbaum, L.V., Kuderavets, R.S., Menshov, O.I. and Gadirov, K.V., 2018. Indicative features of local magnetic anomalies from hydrocarbon deposits: examples from Azerbaijan and Ukraine, Acta Geophysica, doi: 10.1007/s11600-018-0224-0 
Gadirov, V.G. and Eppelbaum, L.V., 2012. Detailed gravity, magnetics successful in exploring Azerbaijan onshore areas. Oil and Gas Journal, 5, 60-73

Gadirov, V.G., 1994. The physical-geological principles of application of gravity and magnetic prospecting in searching oil and gas deposits. Proceed. of 10th Petroleum Congress and Exhibition of Turkey, Ankara, pp. 197-203

Geist, E.L., Childs, J.R. and Scholl, D.W., 1987. Evolution and petroleum geology of Amlia and Amukta intra-arc summit basins, Aleutian Ridge. Marine and Petroleum Geology, 4, 334-352

Griffin, W.R., 1949. Residual gravity in theory and practice. Geophysics, 14, 39-58

Hakimi, M.H., Al-Matary, A.M. and Ahmed, A.., 2017. Bulk geochemical characteristics and carbon isotope composition of oils from the Sayhut sub-basin in the Gulf of Aden with emphasis on organic matter input, age and maturity. Egyptian Journal of Petroleum, https://doi.org/10.1016/j.ejpe.2017.06.002

Hartkopf-Fröder, C., Kloppisch, M., Mann, U., Neumann-Mahlkau, P., Schaefer, R.G. and Wilkes, H., 2007. The end-Frasnian mass extinction in the Eifel Mountains, Germany: new insights from organic matter composition and preservation. Geological Society, London, Special Publications, 278, 173-196. doi: 10.1144/SP278.8

Heroux, Y., Chagnon, A.G. and Bertrand, R., 1979. Compilation and correlation of major thermal maturation indicators. AAPG Bulletin, 63, 2128-2144

Hunt, J.M., 1995. Petroleum Geochemistry and Geology. W.H. Freeman and Company, New York. 743 p.

Ivakhnenko, O.P, Abirov, R. and Logvinenko, A., 2015. New method for characterisation of petroleum reservoir fluid-mineral deposits using magnetic analysis. Energy Procedia, 76, 454-462

Koçyiğit, A., 1987. Hasanoğlan (Ankara) yöresinin tektonostratigrafisi: Karakaya orojenik kuşağının evrimi. Yerbilimleri, 14, 269-293

Li, M., Lou, Z. H., Zhu, R., Jin, A. M. and Ye, Y., 2014. Distribution and geochemical characteristics of fluids in ordovician marine carbonate reservoirs of the Tahe oilfield. Journal of Earth Science, 25, 486-494

Liu, S., Qi, S., Luo, Z., Liu, F., Ding, Y., Huang, H., Chen, Z., Cheng, S., 2018. The origin of high hydrocarbon groundwater in shallow Triassic aquifer in Northwest Guizhou, China. Environmental Geochemistry and Health, 40(1), 415-433

Lyatsky, H.V., Thurston, J.B., Brown, R.J. and Lyatsky, V.B., 1992. Hydrocarbon exploration applications of potential field horizontal gradient vector maps. Canadian Society of Exploration Geophysicists Recorder, 17(9), 10-15

Mathur, S., Jain, V.K., Tripathi, G.K., Jassal, J.K. \& Chandra, K. 1988. Biological marker geochemistry of crude oils of Cambay Basin, India. In: Kumar, R.K., Dwivedi, P., Banerjie, V. \& Gupta, V. (eds) Petroleum Geochemistry and Exploration in the AfroAsian Region. Balkema, Rotterdam, 459-473

Mille, G., Asia, L., Guiliano, M., Malleret, L. and Doumenq, P., 2007. Hydrocarbons in coastal sediments from the Mediterranean Sea (Gulf of Fos area, France). Marine Pollution Bulletin, 54, 566-575

Nettleton, L.L., 1976. Gravity and Magnetics in Oil Prospecting. McGraw-Hill, 464 p.

Okay, A. and Göncüoğlu, C., 2004. The Karakaya complex: A review of data and concepts. Turkish Journal of Earth Sciences, 13, 7795

Onojake, M.C., Osuji, L.C. and Oforka, N.C., 2013. Preliminary hydrocarbon analysis of crude oils from Umutu/Bomu fields, south west Niger Delta Nigeria. Egyptian Journal of Petroleum, 22, 217-224

Özdemir, A., 2019a. Hasanoğlan (Ankara) petrol sisteminin organik hidrojeokimyasal kanıtları. Pamukkale Üniversitesi Mühendislik Bilimleri Dergisi. doi: 10.5505/pajes.2018.12316

Özdemir, A., 2019b. Büyük Menderes grabeni (Batı Anadolu) Neojen öncesi petrol sisteminin organik hidrojeokimyasal kanıtları ve potansiyel kapanlar. Avrupa Bilim ve Teknoloji Dergisi, (16), 325-354

Özdemir, A., 2018. Suda TPH (Toplam Petrol Hidrokarbonları) analizinin petrol ve doğalgaz arama amaçlı kullanımı: Türkiye'den ilk önemli sonuçlar. Mühendislik Bilimleri ve Tasarım Dergisi, 6(4), 615-636

Özdemir, A. and Şahinoğlu, A., 2018. Prospective areas for petroleum exploration and oil \& gas potential of the onshore Hatay (Southern Turkey). 18 International Multidisciplinary Scientific GeoConference (SGEM 2018), 719-726, Doi: $10.5593 /$ sgem2018/1.4/S06.094

Pašteka, R., 2000. 2D semi-automated interpretation methods in gravimetry and magnetometry. Acta Geologica Universitatis Comeniana, 55, 5-50

Peters, K.E., Fraser, T.H., Amris, W., Rustanto, B. and Hermanto, E., 1999. Geochemistry of crude oils from eastern Indonesia. American Association of Petroleum Geologists Bulletin, 83, 1927-1942

Peters, K.E. and Moldowan, J.M., 1993. The Biomarker Guide, Interpreting Molecular Fossils in Petroleum and Ancient Sediments. Englewood Cliffs, Jersey, Prentice Hall, 339-363

Piskarev, A.L. and Tchernyshev, M.Y., 1997. Magnetic and gravity anomaly patterns related to hydrocarbon fields in northern West Siberia. Geophysics, 62(3), 831-841

Ruban, D.A., Al-Husseini, M.I. and Iwasaki, Y., 2007. Review of Middle East Paleozoic Plate tectonics. GeoArabia, 12(3), 35-56

Sakroon, S.A., 2008. Effect of oilfield brine on groundwater quality in Marmul area, Sultanate of Oman. United Arab Emirates University, MSc. Thesis, $146 \mathrm{p}$.

Sar1, A., Bahtiyar, I., Brenner, R.L. and Dogan, A.U., 2003. Potential source rocks for the crude oils in the Ikizce and Tokaris oil fields, SE Turkey. Petroleum Geoscience, 9, 347-356

Satyana, A.H., 2015. Subvolcanic hydrocarbon prospectivity of Java: Opportunities and challenges. Proceedings, Indonesian Petroleum Association. Thirty-Ninth Annual Convention \& Exhibition, May 2015. IPA15-G-105

Sayit, K., 2010. Geochemistry and Petrogenesis of the Oceanic Island and Subduction-Related Assemblages from The Paleotethyan Karakaya Subduction/Accretion Complex, Central and Northwest Turkey. Ortadoğu Teknik Üniversitesi, Yüksek Lisans Tezi, 204 s. 
Sayit, K., Göncüoğlu, M.C., Furman, T., 2010. Petrological reconstruction of Triassic seamounts/oceanic islands within the Palaeotethys: Geochemical implications from the Karakaya subduction/accretion Complex, Northern Turkey. Lithos, 119, 501-511

Sorkhabi, R., 2010. Why So Much Oil in the Middle East ?. Geoexpro, Vol. 7, No. 1

Stephen, O.I. and Iduma, U., 2018. Hydrocarbon potential of Nigeria’s Inland Basin: Case study of Afikpo basin. Journal of Applied Geology and Geophysics, 6(4), 1-24

Svancara, J., 1983. Approximate method for direct interpretation of gravity anomalies caused by surface three-dimensional geologic structures. Geophysics, 48(3), 361-366, https://doi.org/10.1190/1.1441474

Tetiker, S., Yalçın, H. ve Bozkaya, Ö., 2015. Karakaya karmaşığının düşük dereceli metamorfik tarihçesine klorit mineralojisi ve jeokimyası ile yaklaşımlar. Türkiye Jeoloji Bülteni, 58(2), 55-83

Tissot, B.P. and Welte, D.H., 1984. Petroleum Formation and Occurrence. Springer-Verlag, 699 p.

Tran, K.L. and Philippe, B., 1993. Oil and rock extract analysis. in Applied Petroleum Geochemistry (M.L., Bordenave, eds.), p. 373394

Thompson, J.G., 1982. Hydrocarbon source rock analyses of Pakawau Group and Kapuni Formation sediments, northwest Nelson and offshore South Taranaki, New Zealand. New Zealand Journal of Geology and Geophysics, 25(2), 141-148, DOI:10.1080/00288306.1982.10421406

Töpfer, K.D., 1977. Improved technique for rapid interpretation of gravity anomalies caused by two-dimensional sedimentary basins. Journal of Geophysics, 43, 645-654 (in Švancara, J., 1983. Approximate method for direct interpretation of gravity anomalies caused by surface three-dimensional geologic structures. Geophysics, 48(3), 361-366, https://doi.org/10.1190/1.1441474

Ulmishek, G.F. and Klemme, H.D., 1991. Depositional controls, distribution and effectiveness of world's petroleum source rocks. U.S. Geological Survey, 59 p.

Volkman, J.K. and Maxwell, J.R., 1986. Acyclic isoprenoids as biological markers. In: Biological Markers in the Sedimentary Record (R.B. Johns, eds.), Elsevier, New York; pp. 1-42

Waples, D.W., 1985. Geochemistry in Petroleum Exploration. International Human Resources Development Corp., 232 p. 